\title{
Biomarkers in Source Rocks from Barreirinha Formation (Devonian): Distribution and Paleoenvironment Significance
}

\author{
Andrenilton F. Silva, ${ }^{a}$ Artur L. C. Barros, ${ }^{a}$ Alek A. C. Sousa, ${ }^{\circledR a}$ Daniel M. Jarvie, ${ }^{b}$ \\ Sebastian M. Calderón, ${ }^{c}$ Ailton S. Brito, ${ }^{c}$ Afonso C. R. Nogueira, ${ }^{c}$ Alexandre A. de Souza ${ }^{a}$ \\ and Sidney G. de Lima ${ }^{\oplus * a}$ \\ ${ }^{a}$ Programa de Pós-Graduação em Química, Laboratório de Geoquímica Orgânica, \\ Centro de Ciências da Natureza, Universidade Federal do Piauí, 64049-550 Teresina-PI, Brazil \\ ${ }^{b}$ Energy Institute, Texas Christian University, 2901 W. Lowden St., Fort Worth, Texas 76109, USA \\ 'Faculdade de Geologia, Instituto de Geociências, Universidade Federal do Pará, Guamá, \\ 66075-900 Belém-PA, Brazil
}

\begin{abstract}
The Barreirinha Formation-Upper Devonian, is the main petroleum source rock of the Amazon Basin, deposited during the great Devonian Transgression, contributing to significant accumulations of organic matter (OM) in anoxic conditions, which allowed its preservation. The present work had the objective of characterizing the molecular composition of biomarkers in outcrops samples of the Barreirinha Formation, aiming to evaluate the paleoenvironment, thermal evolution, and the preservation of OM total organic carbon (TOC) and Rock-Eval pyrolysis indicate considerable amounts of immature OM deposited in a low oxygenation environment. Gas chromatographymass spectrometry (GC-MS) and gas chromatography-tandem mass spectrometry (GC-MS/MS) data corroborate that the OM was deposited in a suboxic to the oxic environment and low salinity (absence or low relative abundance of $\beta$-carotane and gammacerane). 24- $N$-Propyl-cholestane was detected and identified by synthetic pattern co-injection. High concentrations of tetracyclic polyprenoids (TPPs) in ascending order from base to top, high hopane/sterane ratios, to suggest that the samples had a high molecular weight $n$-alkanes, $\mathrm{C}_{29}$ steranes, low thermal evolution, and anoxic depositional paleoenvironment.
\end{abstract}

Keywords: Amazon Basin, Devonian, Barreirinha Formation, tetracyclic polyprenoids, 24-n-propyl-cholestane $\left(\mathrm{C}_{30}-\mathrm{npc}\right)$

\section{Introduction}

The graytoblack shales of the Barreirinha Formation record the highest marine incursion in the western portion of the Gondwana continent. ${ }^{1,2}$ The marine flood from the Tethys Ocean began in the Mesodevonian and entered the Amazon Basin through the Marajó Island region. ${ }^{3}$ This maximum flood left a record of thick coarsening upward succession of highly radioactive organic-rich black shales, gray shale, siltstone, and sandstone., ${ }^{4,5}$

Previous studies have shown that organic carbon content can reach up to $10 \% .^{2}$ Commercial oil accumulations were identified during the 1950s, as well as large evaporite

*e-mail: sidney@ufpi.edu.br

Editors handled this article: Eduardo Carasek and Ivo M. Raimundo Jr. (Associate) reserves that remain unexplored in the subsurface, and gas reserves discovered near the capital Manaus. ${ }^{6}$ The geochemical characterization of the source rocks of the Amazon Basin, mainly through biomarkers, is of great relevance to understanding the deposition environment, quality and content of organic matter, and generating potential evaluation.

The intracratonic Amazon Basin is located between the Guyana cratons in the north and Brazil in the south, with approximately $500,000 \mathrm{~km}^{2}$. It covers part of the states of Pará and Amazonas, separating east of the Marajó Basin and west of the Solimões Basin, through the Gurupá and Purús Arches, respectively (Figure 1) ${ }^{4,7}$ Its origin is related to the dispersion of efforts during the closing of the Brasiliano Proterozoic Cycle during the Brasiliano/Pan-African Orogeny. ${ }^{8}$ The sedimentary Basin fill reaches a thickness of 
around 5,000 $\mathrm{m}$ of sedimentary and igneous rocks, ${ }^{7}$ divided by Cunha $e^{2}$ al. $^{3}$ into two first-order megassquences: the Paleozoic sequence and the Meso-Cenozoic sequence, separated by a regional unconformity. The Paleozoic Megasequence is made up of four second-order sequences, essentially siliciclastic sedimentation of the Ordovician to the Permian, with a considerable volume of Mesozoic diabase dike and sill intrusions. ${ }^{7}$

The rocks with the greatest potential for hydrocarbon generation in the Amazon Basin are the Devonian shales of the Barreirinha Formation. These shales are inserted in a transgressive context deposited during the Frasnian to the Famenian..$^{911}$ The Devono-Tournaisian Sequence comprises a transgressive-regressive cycle ${ }^{7}$ formed after the Eo-Devonian Caledonian Orogeny unconformity. The sequence consists of neritic to deltaic sandstones and shales at the base, followed by siltstones, shales, and paralytic sandstones, black to dark gray shales, glacial diamictites, finalized by sandstones and marine fluvial siltstones. ${ }^{7,11}$ The Barreirinha Formation is formed by dark gray to black shales, with occasionally silicified $\mathrm{Fe}, \mathrm{Ca}$, and $\mathrm{Mn}$ carbonate concretions. ${ }^{9}$ The unit's sedimentary package records an anoxic marine environment, which has enabled the preservation of a large amount of organic matter during the maximum sequence transgression. ${ }^{2}$

Recent studies have shown that Barreirinha Formation has a thickness of $350 \mathrm{~m}$ in the Basin depocenter. ${ }^{7}{ }^{12} \mathrm{It}$ is composed of three distinct members: Abacaxis Member
(75 m, basal member), composed of dark gray and black charcoal shales, with type II kerogen, euxinic marine environment, having the characteristic of being the main potential source rocks of the Basin ${ }^{11,13,14}$ and corresponds to the maximum flood surface. ${ }^{4}$ The second member, Urubu Member (medium member), $70 \mathrm{~m}$ thickness, also represented by dark gray, little fissile shales with low levels of siltstones, being deposited in a slightly regressive distal marine environment. ${ }^{7}$ The upper member, Urariá Member is characterized by light to dark gray shales, which document weakly regressive marine sedimentation ${ }^{11}$ featuring a suboxide/anoxide condition. This member has the presence of Spirophyton and Protosalvinia plants. ${ }^{11,12,15}$

The dense vegetation cover that predominates in the Amazon region limits the exposure of rocks, added to the intense physical-chemical weathering that prevails in the region, hindering the geological and geochemical study of outcrop rocks. This limitation is reflected in the few works on the Amazon Basin when compared to other Brazilian intracratonic Basins, especially when the focus is on organic geochemistry. In this sense, the purpose of this work is the use of classical chromatographic techniques to study the geochemical biomarkers that help in understanding the sedimentation environment, redox conditions, types of organisms that contributed to deposited organic matter $(\mathrm{OM})$, as well as sequence sedimentary geology of outcrop samples from the Barreirinha Formation (Devonian-Amazon Basin), collected at the southeastern edge of the Basin.

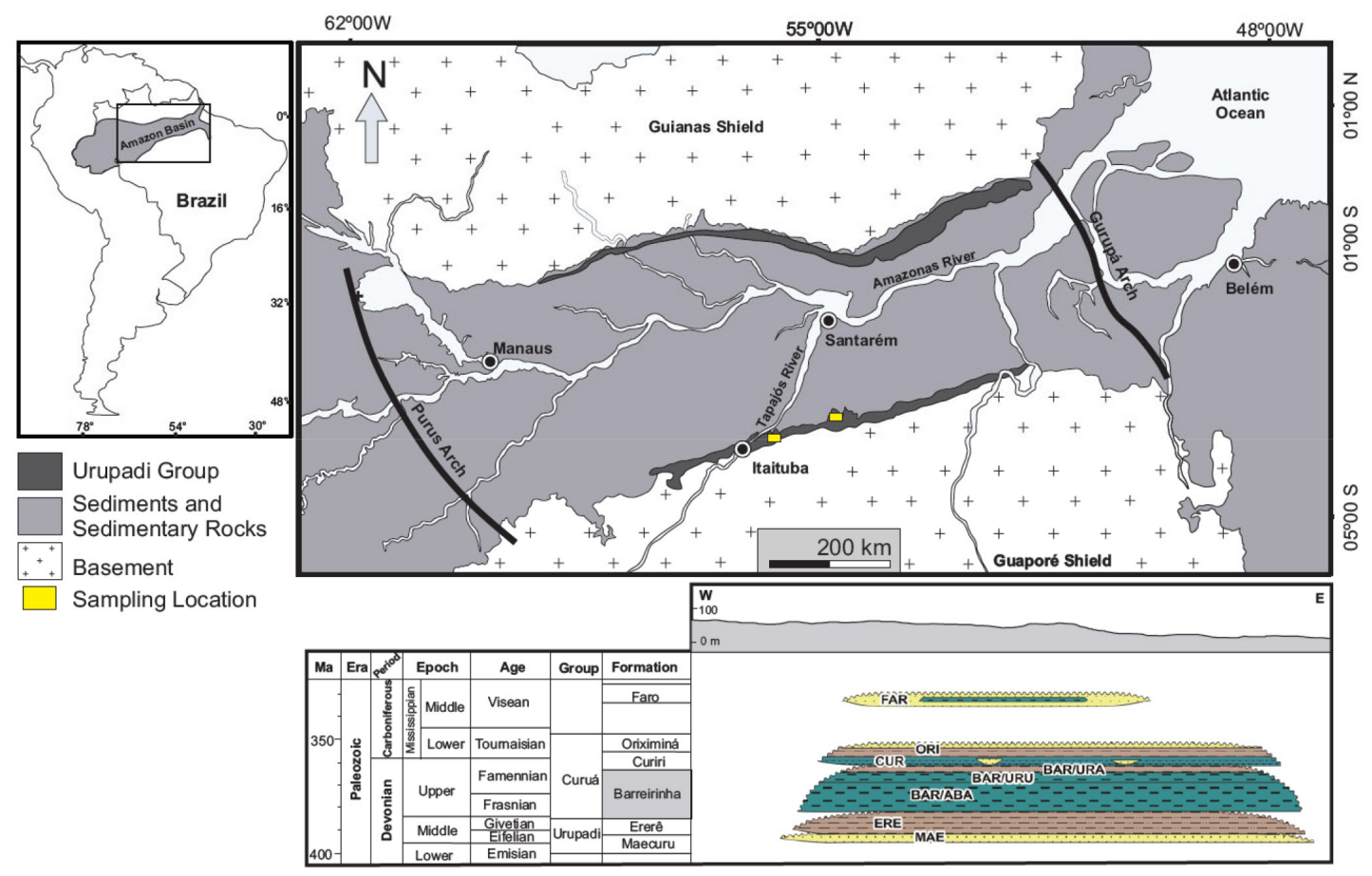

Figure 1. The Amazon Basin location map with outcrop distribution of the Barreirinha Formation (Urupadi group). The stratigraphic succession of Urupadi group (Barreirinha Formation highlighted), was adapted from Cunha $e t$ al. ${ }^{7}$ 


\section{Experimental}

\section{Sample collection}

About $500 \mathrm{~g}$ of sample in outcrops near the Tapajós River (45'18"S, 54 54'51"W) approximately $1,170 \mathrm{~km}$ from the city of Belém (Figure 1), consisting of shales with flat-parallel lamination were collected, avoiding wear and contamination with other materials, packed with aluminum, and later stored in identified plastic bags.

\section{Total organic carbon (TOC) analysis and Rock-Eval pyrolysis}

After spraying (80 mesh), $1 \mathrm{~g}$ of the samples weighed in a porcelain crucible were acidified with $\mathrm{HCl}(1: 1)$ and hot for $6 \mathrm{~h}$ to remove the inorganic carbon. Then, the samples were dried in an oven at $80{ }^{\circ} \mathrm{C}$ for $12 \mathrm{~h}$ and sent for TOC and S (sulfur) analysis in the Leco Carbon Analyzer LECO SC-632 at the Laboratory of Chemical Stratigraphy and Organic Geochemistry (LGQM) of the State University of Rio de Janeiro (UERJ). For the analysis of Rock-Eval pyrolysis the methodology used was based on Espitalié et al., ${ }^{16}$ which consists of spraying and sieving 10 to $100 \mathrm{mg}$ of the samples (80 mesh) and then placing them in steel crucibles for subsequent analysis in a Vinci Rock-Eval 6 microwave oven with an inert atmosphere at $650^{\circ} \mathrm{C}$, using nitrogen as the carrier gas. The measurement of TOC and sulfur is performed with a thermal conductivity detector, being recorded as a percentage by weight of the rock.

\section{X-ray diffraction analysis (XRD)}

The diffraction patterns of the samples were collected using a Shimadzu XRD 6000 (Shimadzu, Kyoto, Japan) diffractometer with a copper radiation source ( $\mathrm{Cu} \mathrm{K \alpha}=1.5406 \AA)$ using the powder method, which basically consists of accommodating a certain mass of the sample on support (glass, borosilicate), then submitting it to diffraction. The operating conditions used in the analyzes comprised a $2 \theta$ interval between 5 and $90^{\circ}$ (degrees), with a scanning speed of $2^{\circ} \mathrm{min}^{-1}$, with a pass of $0.02^{\circ}$.

\section{Soluble organic matter extraction (SOM) and fractionation}

About $150 \mathrm{~g}$ of pulverized rock was subjected to continuous extraction of OM for $24 \mathrm{~h}$ in a Soxhlet system using as extraction solvent a mixture of dichloromethane (Scharlau, Spain)/methanol (Tedia, Fairfild, United State of America) (DCM/MeOH) $12 \%$ and metallic copper to remove elemental sulfur. After extraction, the solvent was evaporated on a rotary evaporator, the concentrated extracts were weighed for yield calculation and then conditioned in desiccators.

The fractionation was performed in an open column, having as stationary phase silica:alumina $\left(\mathrm{SiO}_{2}: \mathrm{Al}_{2} \mathrm{O}_{3}\right)$ in a 1/1.2 ratio ( $2.5 \mathrm{~g}: 3 \mathrm{~g})$ and being sequentially eluted with hexane (Bio-Grade, San Francisco, United State of America) (fraction F1) containing mainly saturated hydrocarbons; hexane/dichloromethane (DCM) (8:2, fraction F2) containing mainly aromatic hydrocarbons and DCM/MeOH (3:1, fraction F3) containing heteroatomic compounds. All solvents were treated and bidistilled. The silica gel used in column was 60 mesh (0.0063-0.2 nm/70-230 mesh, Sigma-Aldrich, São Paulo, Brazil), and type WN-6 alumina (70-290 mesh, Sigma-Aldrich, St. Louis, United State of America).

\section{Gas chromatography-mass spectrometry (GC-MS)}

The saturated fraction $\left(10 \mathrm{mg} \mathrm{mL}^{-1}\right)$ was analyzed using a Shimadzu GCMS-QP2010 SE, AOC-500 (Shimadzu, Kyoto, Japan) system under the following analysis conditions: split ratio was $1: 1$, injector temperature $290^{\circ} \mathrm{C}$

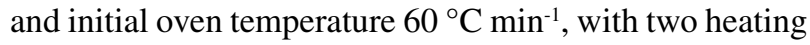
ramps, one of $6{ }^{\circ} \mathrm{C} \mathrm{min}{ }^{-1}$ to $280{ }^{\circ} \mathrm{C}$ remaining for $5 \mathrm{~min}$; the second $1{ }^{\circ} \mathrm{C} \mathrm{min}{ }^{-1}$ to $315^{\circ} \mathrm{C}$ remaining for $15 \mathrm{~min}$ and interface temperature $300^{\circ} \mathrm{C}$. Component chromatography was performed using an Rtx-5MS column, $30 \mathrm{~m} \times 0.25 \mathrm{~mm}$, an internal film thickness of $0.25 \mu \mathrm{m}$, helium as a carrier gas $\left(5.0 \mathrm{~mL} \mathrm{~min}^{-1}\right)$, and an impact energy of $70 \mathrm{eV}$. Mass spectra were acquired in full scan mode with a mass range from $\mathrm{m} / \mathrm{z} 47$ to 650 , with a total time of $80 \mathrm{~min}$.

\section{Gas chromatography-tandem mass spectrometry (GC-MS/MS)}

The saturated fraction $\left(10 \mathrm{mg} \mathrm{mL}^{-1}\right)$ was analyzed by GC-MS/MS and performed on a ThermoScientific TRACE GC Ultra model coupled to a TSQ Quantum XLS Triple Quadrupole mass spectrometer under the following analysis conditions: split ratio was 1:10, injector temperature was $290{ }^{\circ} \mathrm{C}$ and initial oven temperature of $80{ }^{\circ} \mathrm{C}$ for $4 \mathrm{~min}$, featuring a heating ramp, one being $6{ }^{\circ} \mathrm{C} \mathrm{min}^{-1}$ to $300{ }^{\circ} \mathrm{C}$ remaining for $5 \mathrm{~min}$ and interface temperature $300{ }^{\circ} \mathrm{C}$. For component chromatography, an EquityTM-1, PerkinElmer column, $30 \mathrm{~m} \times 0.25 \mathrm{~mm}$, internal film thickness of $0.10 \mu \mathrm{m}$, helium as a carrier gas, and impact energy of $70 \mathrm{eV}$ was employed. Mass spectra were acquired in full scan mode with a mass range of $\mathrm{m} / \mathrm{z} 50$ to $650 \mathrm{Da}$, with a total time of $92.66 \mathrm{~min}$. The transitions selected for each biomarker class were based 
on the molecular ion $\left(\mathrm{M}^{+} \bullet\right)$ for the precursor and the peak base $(\mathrm{PB})$ for the product $\left(\mathrm{M}^{+} \bullet \rightarrow \mathrm{PB}\right)$.

\section{Quantification}

Linear and isoprenoid alkanes were quantified by the internal quantitation method by the addition of $50 \mu \mathrm{g}$ of 3-methylheneicosane ( $\mathrm{a} i-\mathrm{C}_{22}, 99 \%$ purity; ULTRA Scientific, North Kingstown, United State of America) before GC-MS analysis. Biomarkers (terpanes and steranes) were also quantified by the same internal quantification method by adding $0.1 \mu \mathrm{g}$ of $5 \beta(\mathrm{H})$-cholane (Chiron, Norway) without adjustments for possible response differences.

\section{Results and Discussion}

\section{TOC, Rock-Eval, and SOM}

The samples studied had total organic carbon (TOC) content between 1.08 and $3.23 \%$ and sulfur content between 0.23 and $1.5 \% . \mathrm{S}_{2}$ values ranging from 1.09 to $8.17 \%$ and hydrogen index (HI) between 100.93 and $306.7 \mathrm{mg} \mathrm{HC} \mathrm{g}^{-1}$ TOC. The productivity index (PI) is between 0.01 and 0.04 (Table 1). Soluble organic matter (SOM) yielded between 0.05 and $1.4 \%$. Saturated, aromatic and NSO fractions (polar fraction) ranged from 15.6-45.8, 2.4-21 and 40.2-69.8\%, respectively.

\section{Sedimentology and mineral geochemistry}

The studied succession is dominated by finely laminated shales. In the upper portion, the shale occurs interbedded fine massive sandstone. According to the XRD results performed, the mineralogical composition of the analyzed material is composed mainly of quartz (Qtz) followed by pyrite (Py), vermiculite ( Ve), kaolinite (Ka), and muscovite (Mu) or illite (Il) (Figure 2). The deposits are interpreted as formed in a marine environment developed under deep to transitional shelf conditions.

The black to dark grey shales with pyrite are indicative of reducing conditions during the Upper Devonian. On the other hand, the dominance of quartz within the clay particles framework suggests sedimentary material of continental origin possibly related to the continuous fluvial input attested by the upward increase of sand material (Figure 2). ${ }^{17-21}$

\section{Geochemical characteristics}

The distribution of $n$-alkanes in the samples ranged from $n-\mathrm{C}_{12}$ to $n-\mathrm{C}_{36}$ (Figure 3 ). The range of hydrocarbons (HC) of $n-\mathrm{C}_{19}-n-\mathrm{C}_{24}$ was predominant about the other ranges, except for samples BA-01 and BA-07, which presented predominance of $\mathrm{HC}$ in the range of $n-\mathrm{C}_{13}-n-\mathrm{C}_{18}$ (Figure 3 , Table 2). Additionally, quantification data are presented in Supplementary Information (SI) section.

Table 1. Results were obtained for TOC analysis, Rock-Eval pyrolysis, sample extraction, and fractionation

\begin{tabular}{|c|c|c|c|c|c|c|c|}
\hline \multirow{2}{*}{ Parameter } & \multicolumn{7}{|c|}{ Sample } \\
\hline & BA-01 & BA-02 & BA-03 & BA-04 & BA-05 & BA-06 & BA-07 \\
\hline TOC / wt. \% & 3.23 & 3.06 & 3.08 & 1.08 & 2.0 & 1.96 & 1.94 \\
\hline $\mathrm{T}_{\max } /{ }^{\circ} \mathrm{C}$ & 434 & 436 & 433 & 435 & 436 & 438 & 437 \\
\hline $\mathrm{S}_{1} /\left(\mathrm{mg} \mathrm{HC} \mathrm{g}^{-1}\right.$ rock $)$ & 0.16 & 0.13 & 0.14 & 0.05 & 0.05 & 0.04 & 0.03 \\
\hline $\mathrm{S}_{2} /\left(\mathrm{mg} \mathrm{HC} \mathrm{g}^{-1}\right.$ rock $)$ & 8.17 & 8.08 & 4.31 & 1.09 & 5.95 & 5.35 & 5.69 \\
\hline $\mathrm{S}_{3} /\left(\mathrm{mg} \mathrm{CO}_{2} \mathrm{~g}^{-1}\right.$ rock $)$ & 0.25 & 0.27 & 0.39 & 0.12 & - & - & - \\
\hline $\mathrm{HI} /\left(\mathrm{mg} \mathrm{HC} \mathrm{g}^{-1} \mathrm{TOC}\right)$ & 252.94 & 264.05 & 139.94 & 100.93 & 306.7 & 272.95 & 284.5 \\
\hline $\mathrm{OI} /\left(\mathrm{mg} \mathrm{CO}_{2} \mathrm{~g}^{-1} \mathrm{TOC}\right)$ & 7.74 & 8.82 & 12.66 & 11.11 & nd & nd & nd \\
\hline $\mathrm{S} / \%$ & 1.0 & 1.5 & 0.77 & 1.4 & 0.36 & 0.23 & 0.25 \\
\hline PI & 0.02 & 0.02 & 0.03 & 0.04 & 0.01 & 0.01 & 0.01 \\
\hline \multicolumn{8}{|l|}{ Yield / \% } \\
\hline SOM & 0.16 & 0.08 & 0.1 & 0.05 & 0.92 & 1.4 & 1.4 \\
\hline Sat. & 19.8 & 27 & 22.7 & 45.8 & 27.8 & 20.5 & 15.6 \\
\hline Aro. & 16.8 & 18.8 & 21 & 14 & 2.4 & 13 & 5.4 \\
\hline NSO & 63.4 & 69.2 & 56.3 & 40.2 & 69.8 & 66.5 & 79 \\
\hline Sat./Aro. & 1.18 & 1.44 & 1.08 & 3.27 & 11.58 & 1.58 & 2.89 \\
\hline
\end{tabular}

TOC: total organic carbon; $\mathrm{T}_{\max }$ : peak temperature of pyrolysis; $\mathrm{S}_{1}$ : residual hydrocarbon; $\mathrm{S}_{2}$ : pyrolysis hydrocarbon; $\mathrm{S}_{3}$ : the amount of $\mathrm{CO}_{2}$ produced during pyrolysis of kerogen; HI: hydrogen index $=100 \times \mathrm{S}_{2} \mathrm{TOC}^{-1}$; OI: oxygen index $=100 \times \mathrm{S}_{3} \mathrm{TOC}^{-1}$; $\mathrm{S}$ : percentage of sulfur; PI: productivity index $\mathrm{S}_{1} /\left(\mathrm{S}_{1}+\mathrm{S}_{2}\right)$; SOM: soluble organic matter; Sat: saturated fraction; Aro: aromatic fraction; NSO: polar fraction. Values of $T_{\text {max }}$, $S_{1}$, $S_{2}$ and $S_{3}$ are obtained from the Rock-Eval analysis; nd: not detected. 


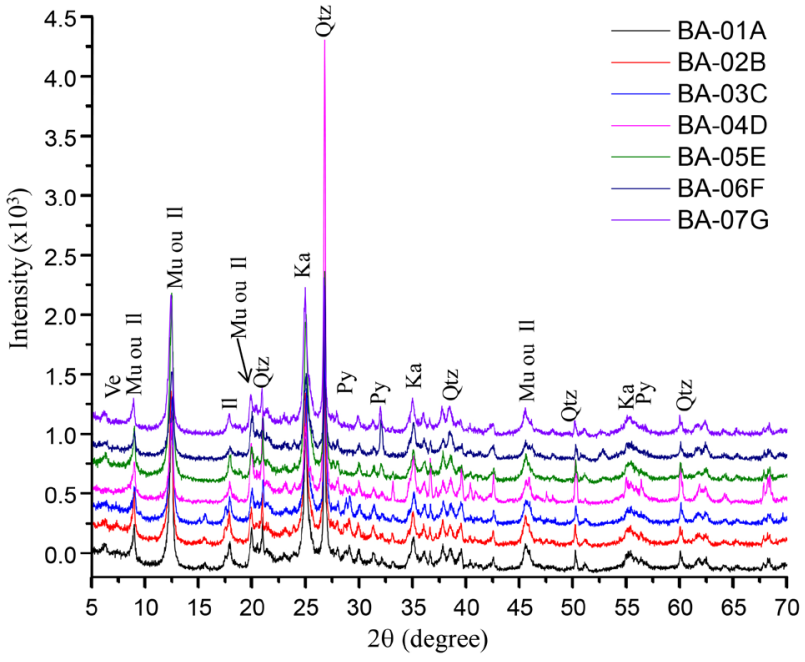

Figure 2. XRD diffractograms of the shales studied. Ve: vermiculite; Mu: muscovite; Il: illite; Qtz: quartz; Ka: kaolinite; Py: pyrite.

The carbon preference index (CPI) and odd even predominance (OEP) values (Table 2) ranged from $1.07-1.17$ to $0.87-1.41$, respectively. The ratio that associates the contribution of terrestrial to aquatic OM, terrigenoous/ aquatic ratio (TAR) ranged from 0.41-1.30 (Table 2). The ratio for the pristane (Pr) and phytane $(\mathrm{Ph})$ acyclic isoprenoids, $\mathrm{Pr} / \mathrm{Ph}$, ranged from 0.29 to 3.87 (Table 2). The $\mathrm{Pr} / n-\mathrm{C}_{17}$ and $\mathrm{Ph} / n-\mathrm{C}_{18}$ ratios that are associated with maturity and biodegradation are in the range of 0.10-1.88 and $0.19-0.91$, respectively. The distribution (bottom to top, BA-01-BA-07) of cyclohexanes ranging from $\mathrm{C}_{13}-\mathrm{C}_{35}$, with a predominance of odd and maximum chains at $\mathrm{C}_{17}$ is shown in Figure $4(\mathrm{~m} / \mathrm{z} 82)$.

The typical distribution of steranes and diasteranes is shown in Figure 5 by GC-MS/MS analysis corresponding to $\mathrm{C}_{27}-\mathrm{C}_{30}$ ions $\left(\mathrm{M}^{+} \bullet \rightarrow m / z, 217\right)$. Rearranged steranes (diasteranes) are observed in all samples and the relationship between diasteranes and regular steranes was high, ranging from 0.35 to 0.85 (Table 3 ). The index value of diasteranes ranged from 77.84 to 98.16 (Table 3). The hopane/sterane (Hop./Ste.) (Table 3) presented values between 4.81-51.35.

The distribution of bicyclic sesquiterpanes monitored in all samples is shown in Figure 6 (base, midpoint, and top). Rearranged driman (III), drimano (VI), and homodriman (XI) were the main constituents identified. Pentacyclic hopane distribution was monitored by $m / z, 191$ (Figure 7, typical GC-MS/MS in Figure S4, SI section). The $\mathrm{Ts} / \mathrm{Tm}$ and $\mathrm{Ts} /(\mathrm{Ts}+\mathrm{Tm})$ ratios ranged from $0.19-0.45$ to $0.16-0.31$, respectively. The relative abundance of $\mathrm{C}_{29}$-norhopano was lower than $\mathrm{C}_{30}$-hopano with ratios ranging between 0.56-0.77.

$\mathrm{C}_{31}$-Homohopanes have a higher relative abundance (Figure 7), decreasing in the direction of $\mathrm{C}_{34}$-homohopanos, being $\mathrm{C}_{35}$-homohopano detected in only three of the studied samples. The distribution of $\mathrm{C}_{29}$-morethane to $\mathrm{C}_{34}$-homomoretane was also identified. The ratio $\mathrm{C}_{30} / \Sigma \mathrm{C}_{31}-\mathrm{C}_{35}$ ranged from 0.49-1.27. The $\mathrm{C}_{31}-\mathrm{C}_{35} \alpha \beta S / S+R$ ratios were calculated (Table 4 ) and their values ranged around 0.55 . The ratios $\alpha \beta 29 / \alpha \beta 30$ and $\alpha \beta 31 / \alpha \beta 30$ ranged from $0.67-0.77$ to $0.17-0.40$, respectively (Table 4 ). The presence of tetracyclic polyprenoids (TPPs) was monitored by the reconstructed ion chromatogram (RIC) $\mathrm{m} / \mathrm{z} 259$, with a ratio ranging between 0.10 and 2.12 (Table 3 ).

\section{Organic matter contribution}

The van Krevelen type diagram correlates the oxygen index (OI, Table 1) and hydrogen index (HI, Table 1), thus

Table 2. Calculated parameters (based on signal area) for the studied samples

\begin{tabular}{|c|c|c|c|c|c|c|c|}
\hline \multirow{2}{*}{ Parameter } & \multicolumn{7}{|c|}{ Sample } \\
\hline & BA-01 & BA-02 & BA-03 & BA-04 & BA-05 & BA-06 & BA-07 \\
\hline $\mathrm{Pr} / \mathrm{Ph}$ & 2.35 & 1.95 & 2.21 & 2.23 & 0.29 & 3.87 & 3.28 \\
\hline $\mathrm{Pr} / n-\mathrm{C}_{17}$ & 1.83 & 1.65 & 1.88 & 0.44 & 0.10 & 0.59 & 0.51 \\
\hline $\mathrm{Ph} / n-\mathrm{C}_{18}$ & 0.88 & 0.73 & 0.91 & 0.22 & 0.20 & 0.19 & 0.19 \\
\hline CPI & 1.16 & 1.15 & 1.16 & 1.07 & 1.16 & 1.17 & 1.15 \\
\hline OEP & 1.08 & 0.91 & 1.12 & 1.03 & 0.92 & 0.87 & 1.41 \\
\hline TAR & 0.59 & 1.30 & 0.73 & 0.88 & 1.27 & 1.26 & 0.41 \\
\hline \multicolumn{8}{|l|}{$n$-Alkanes } \\
\hline$\Sigma \mathrm{C}_{13}-\mathrm{C}_{18} / \%$ & 30.28 & 14.23 & 25.05 & 25.45 & 25.00 & 20.51 & 31.87 \\
\hline$\Sigma \mathrm{C}_{19}-\mathrm{C}_{24} / \%$ & 21.13 & 37.44 & 26.19 & 31.89 & 35.54 & 38.68 & 30.78 \\
\hline$\Sigma \mathrm{C}_{25}-\mathrm{C}_{30} / \%$ & 13.77 & 23.66 & 17.14 & 21.79 & 23.71 & 25.37 & 19.29 \\
\hline$\Sigma \mathrm{C}_{31}-\mathrm{C}_{35} / \%$ & 2.62 & 6.82 & 3.13 & 7.77 & 3.16 & 3.22 & 2.79 \\
\hline
\end{tabular}

$\mathrm{Pr} / \mathrm{Ph}=$ pristane/phytane in total ion chromatogram (TIC) ${ }^{22} \mathrm{Pr} / n-\mathrm{C}_{17}=$ pristane $/ n-\mathrm{C}_{17}$ in TIC; $; 2 \mathrm{Ph} / n-\mathrm{C}_{18}=$ phytane $/ n-\mathrm{C}_{18}$ in TIC; $; 2 \mathrm{CPI}$ : carbon preference index $=0.5 \times\left[\Sigma_{\text {odd }} n-\mathrm{C}_{23}-n-\mathrm{C}_{31}+\Sigma_{\text {Pair }} n-\mathrm{C}_{25}-n-\mathrm{C}_{29}\right] / \Sigma\left(n-\mathrm{C}_{22}-n-\mathrm{C}_{30}\right)$ in RIC $m / z 71 ; 23$ OEP: odd even predominance $=\left(n-\mathrm{C}_{13}+6 \times n-\mathrm{C}_{15}+n-\mathrm{C}_{17}\right) /\left(4 \times n-\mathrm{C}_{14}+\right.$ $\left.4 \times n-\mathrm{C}_{16}\right)$ in RIC $m / z, 71 ; 24$ TAR: terrigenoous/aquatic ratio $=\Sigma_{\text {odd }} n-\mathrm{C}_{27}-\mathrm{C}_{31} / \Sigma_{\text {odd }}\left(n-\mathrm{C}_{15}-n-\mathrm{C}_{19}\right)$ in RIC $m / z, 71.22$ 


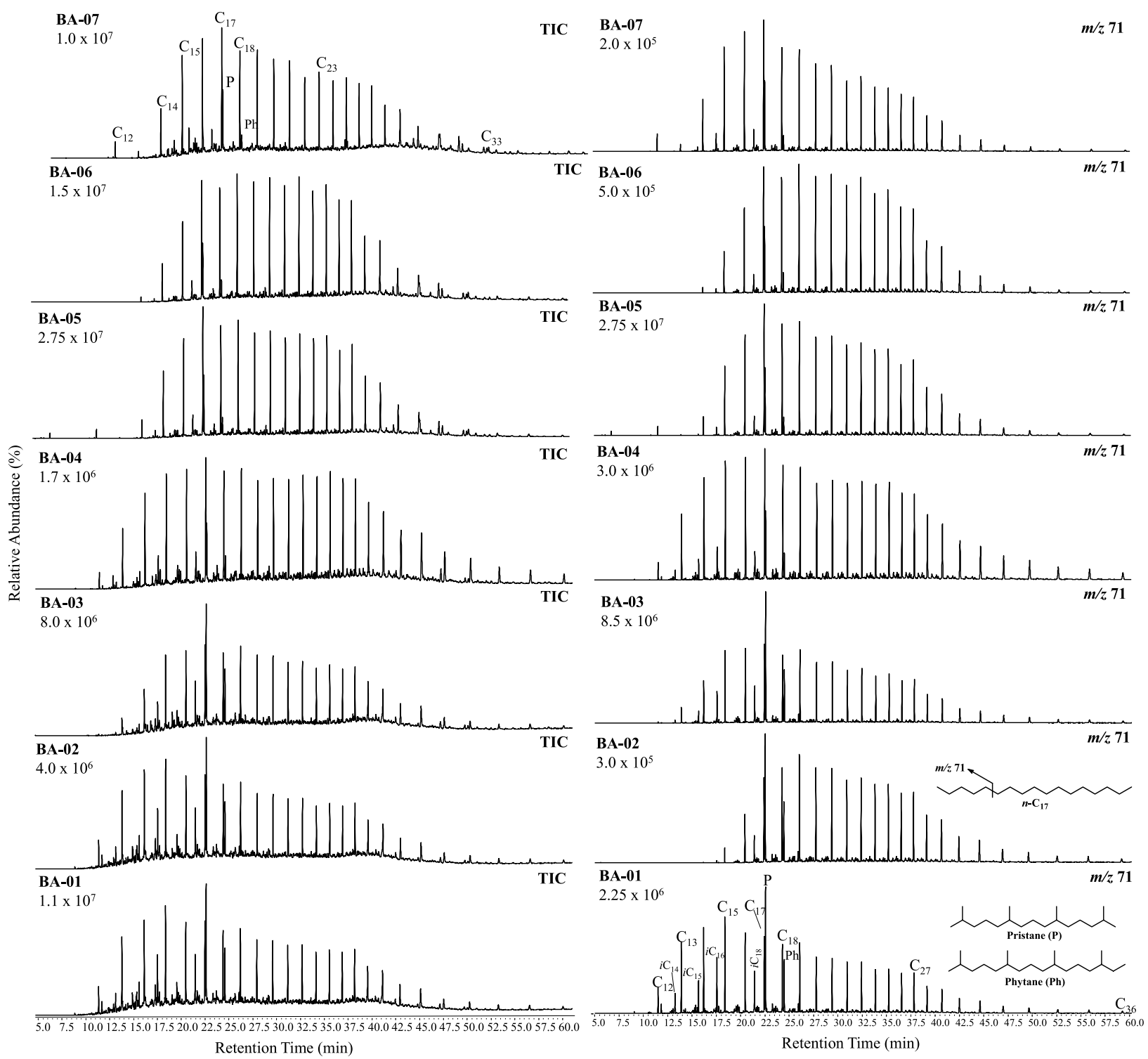

Figure 3. Total ion chromatogram (TIC) and $\mathrm{m} / \mathrm{z}, 71$ chromatograms of Devonian rock extracts.

allowing to characterize the type of deposited OM as type II (phytoplankton, algae, fungi, bacteria, and archaebacteria). This is shown in Figure 8 for the samples studied.

The $n$-alkane contribution can be used to define the contribution of OM from different sources. ${ }^{25}$ The total ion chromatogram (TIC, Figure 3) of the study samples shows a distribution profile of $\mathrm{C}_{12}$ to $\mathrm{C}_{36} n$-alkanes, with an odd overpair predominance and a bimodal distribution, which was evidenced by the monitoring of the ion $m / z, 71$ (Figure 3 ) suggesting a mixed contribution of marine and terrestrial OM. ${ }^{26}$

CPI and OEP values indicate the odd/even predominance of $\mathrm{HC}$ in a specific range. ${ }^{22,26,27}$ These ratios presented values higher than 1 (Table 2) suggesting the contribution of terrestrial input in the studied samples. ${ }^{22}$ Previous studies ${ }^{23,28,29}$ state that short-chain $n$-alkanes $\left(n-\mathrm{C}_{13}-n-\mathrm{C}_{18}\right)$ indicate the contribution of marine OM (phytoplankton and zooplankton) from medium-chain $\left(n-\mathrm{C}_{19}-n-\mathrm{C}_{24}\right)$ are derived from bacteria and long-chain $\left(n-\mathrm{C}_{15}-n-\mathrm{C}_{35}\right)$ come from terrestrial vegetables. Additionally, those with chains between $n-\mathrm{C}_{21}-n-\mathrm{C}_{25}$ may be derived from conifers. ${ }^{30}$

In general, the samples had relatively high intermediate chain $n$-alkanes content $\left(n-\mathrm{C}_{19}-n-\mathrm{C}_{24}\right)$, indicating higher bacterial contribution, except for samples BA-01 and BA-07, which had higher content of $n$-alkane chain relative to $n-\mathrm{C}_{13}-n-\mathrm{C}_{18}$, suggesting a greater contribution of marine OM (Table 2, Figure 3).

The $\mathrm{Pr} / \mathrm{Ph}$ ratio may be affected by different factors such as maturity, depositional environment, and deposited OM. ${ }^{23,28,31-35}$ The sources of the major contribution of these isoprenoids are the chlorophyll side chain of phototrophic 


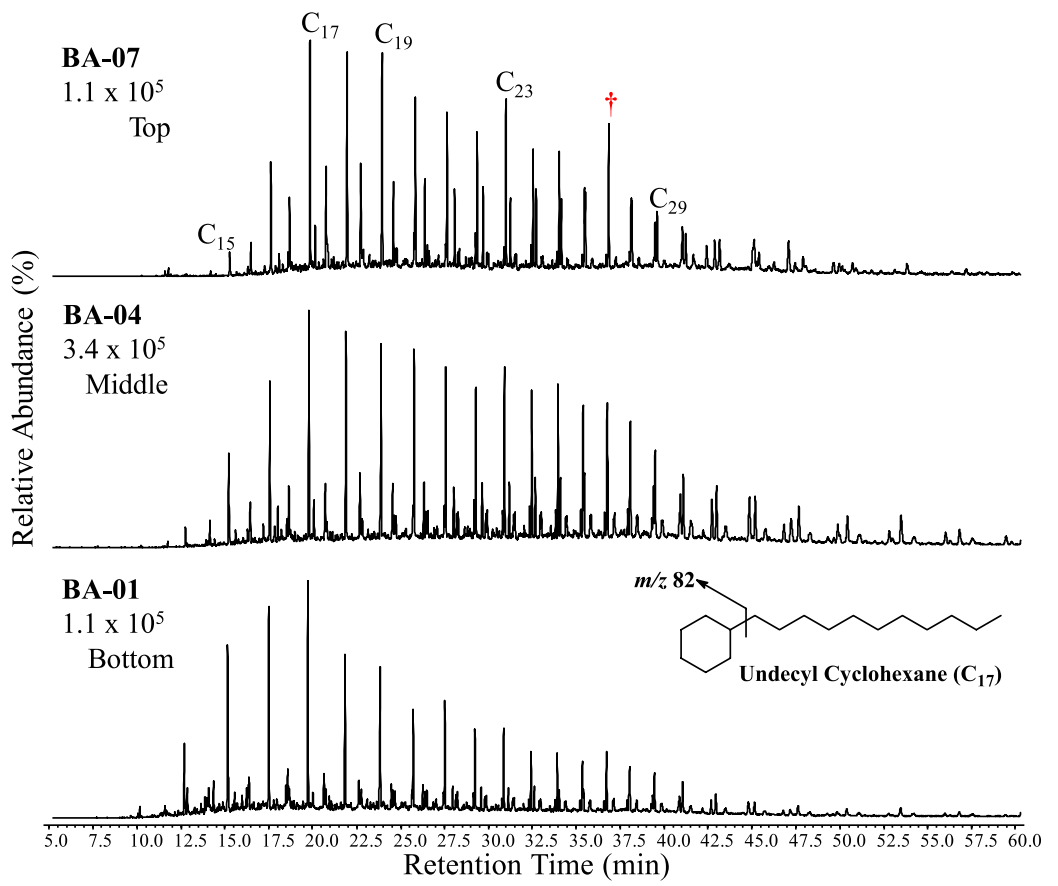

Figure 4. RIC $\mathrm{m} / z$ 82 of the cycloalkanes (cyclohexanes) identified in the samples corresponding to the bottom, middle, and top; $\uparrow$ indicates the coelution between $\mathrm{C}_{27}$ alkyl cyclohexane and $\mathrm{C}_{27} n$-alkane.

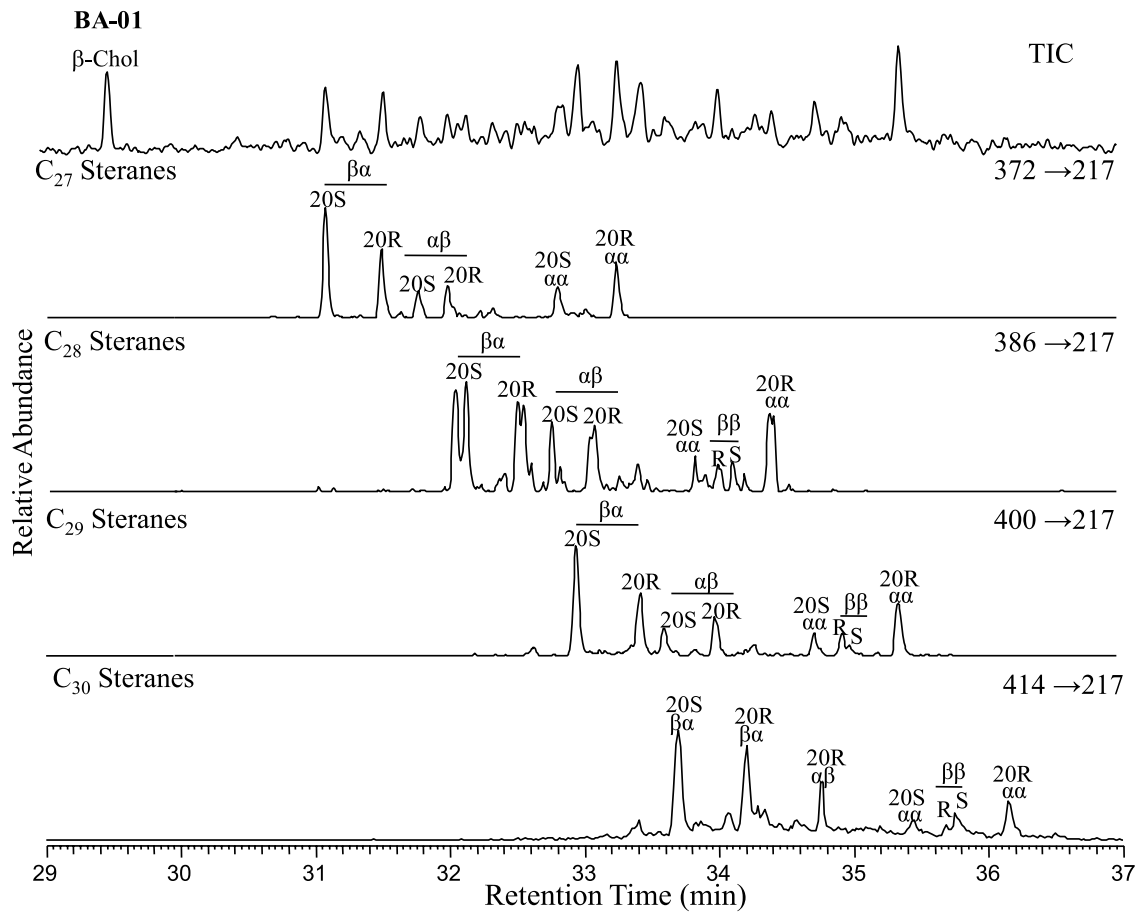

Figure 5. TIC and GC-MS/MS showing typical $\mathrm{C}_{27}-\mathrm{C}_{30}$ distribution of steranes and diasteranes for the samples studied. Symbols $\alpha \beta$ and $\beta \alpha$ indicate isomerization for diasterane carbons 13 and 17 and symbols $\alpha \alpha$ and $\beta \beta$ correspond to carbons 14 and 17 for regular steranes. The symbols $S$ and $R$ indicate the stereochemistry of carbon 20 .

organisms, tocopherols, and bacteriochlorophylls a and $\mathrm{b}$ of purple sulfobacteria. ${ }^{22,31,35} \mathrm{High} \mathrm{Pr} / \mathrm{Ph}$ ratios (> 3.0) reflect the contribution of terrestrial $\mathrm{OM}$ in a moderately oxidizing (suboxide) depositional environment. ${ }^{22}$ From the correlation of the parameters $\operatorname{Pr} / n-\mathrm{C}_{17}$ versus $\mathrm{Ph} / n-\mathrm{C}_{18}$ and $\mathrm{P} / \mathrm{Ph}$ versus $\mathrm{C}_{27} \alpha \alpha \alpha R / \mathrm{C}_{29} \alpha \alpha \alpha R$ (Table 2), it is possible to understand the mixture of algal and terrestrial OM (Figures 9a and 9b).

Isoprenoids such as pristane, phytane, and regulars $\left(i-\mathrm{C}_{13}\right.$ to $i-\mathrm{C}_{20}$ ) can originate from various sources besides the chlorophyll side chain. For example, bacteriochlorophylls $\mathrm{c}, \mathrm{d}, \mathrm{e}$ and $\mathrm{g}$ have esterified farnesic chains that are common 


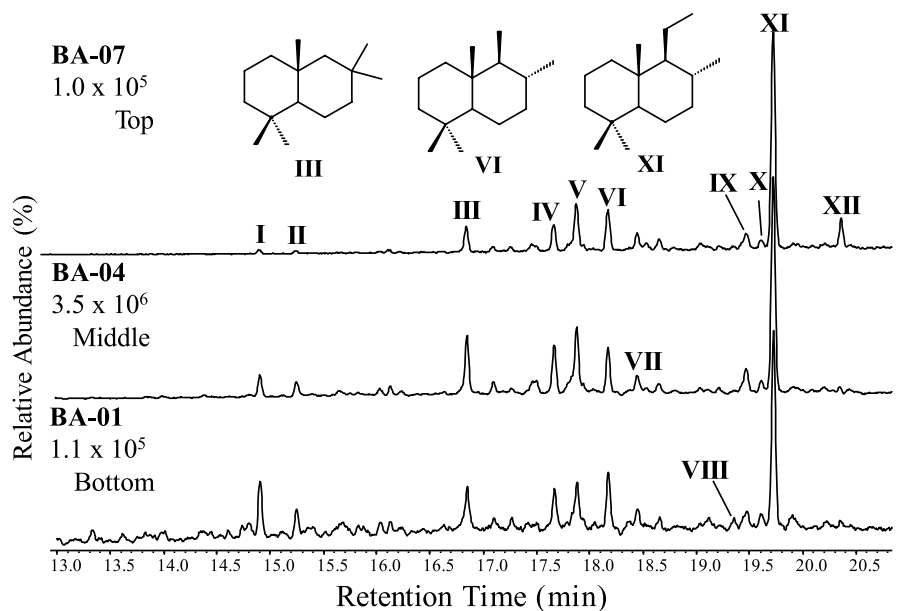

Figure 6. Partial $\mathrm{m} / \mathrm{z} 123$ mass chromatogram for samples BA-01, BA-04, and BA-07 (base, midpoint, and top). Nordrimanes I and II, eudesmane III, drimanes rearranged IV, V and VII, $8 \beta(\mathrm{H})$-drimane VI, rearranged homodrimanes VIII-X, $8 \beta(\mathrm{H})$ - and $8 \alpha(\mathrm{H})$-homodrimanes XI-XII.

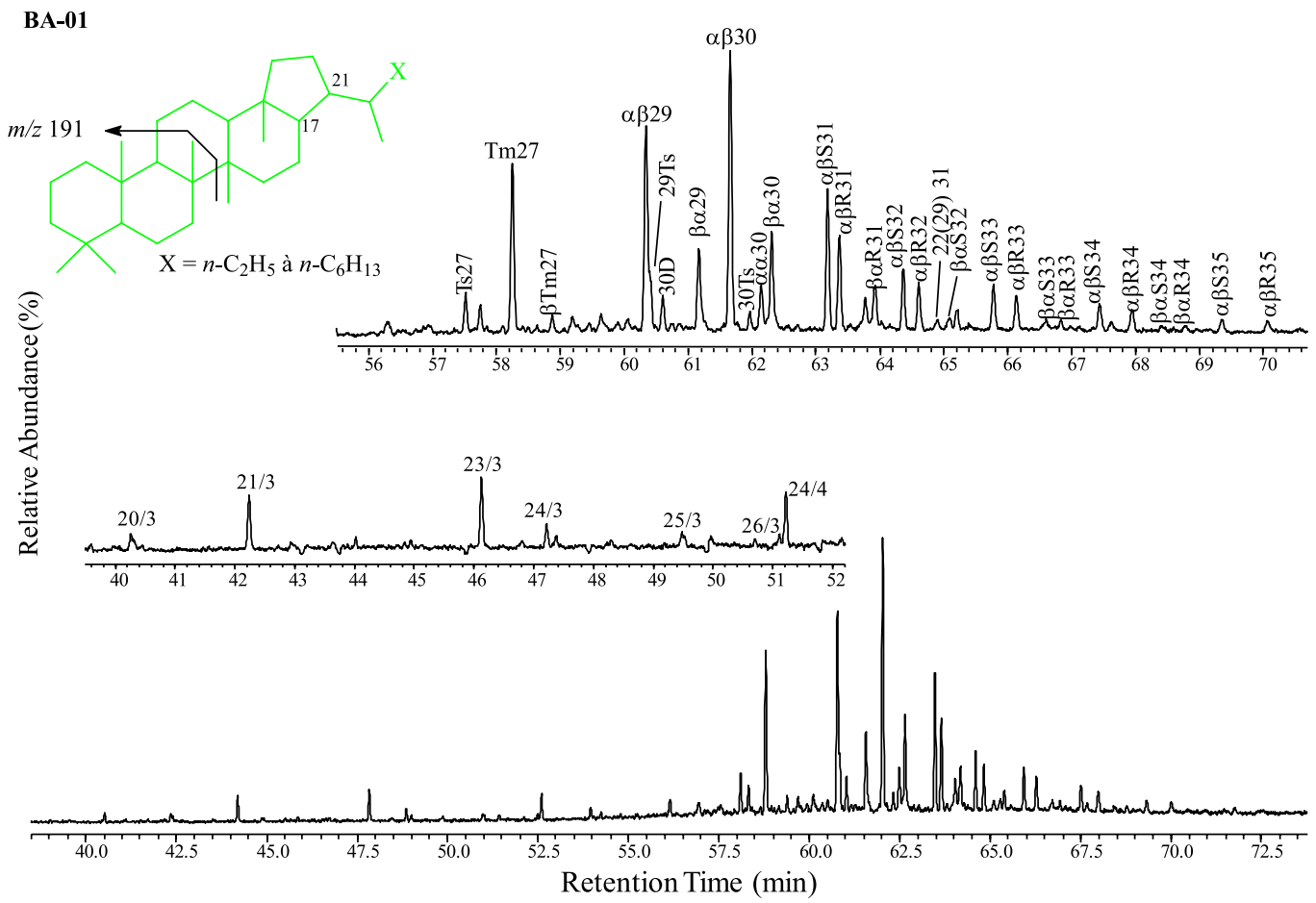

Figure 7. Partial $\mathrm{m} / \mathrm{z} 191$ mass chromatogram of outcrop from BA-01 well. 20/3,21/3, 23/3, 24/3, 25/3, and 26/3 correspond to tricyclic terpanes and 24/4 to tetracyclic terpane. $\alpha \beta$ and $\beta \alpha$ correspond to the stereochemistry of carbons 17 and 21 . Ts: $18 \alpha(\mathrm{H})-22,29,30$-trisnorneohopane; Tm: 17 $\alpha(\mathrm{H})-22.29,30-$ trisnorhopane; 30D: 17 $\alpha(\mathrm{H})$-diahopane.

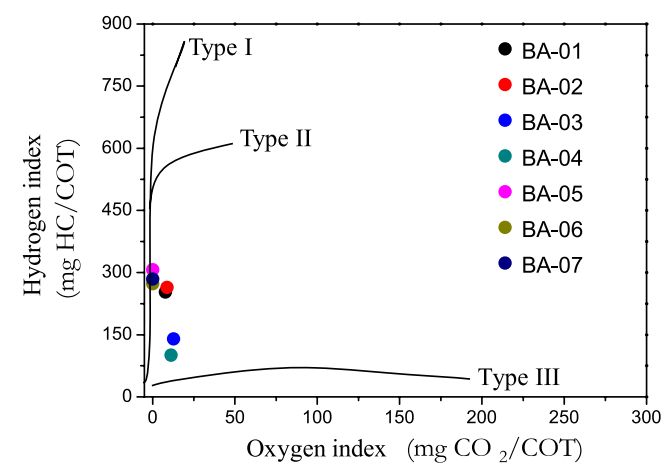

Figure 8. Van Krevelen type diagram for the studied samples. constituents of archeolipids (Chlorobiaceae family), and their saturated analog, isoprenoid $i-\mathrm{C}_{15}$, is indicative of the presence of these organisms as a contributor to OM. ${ }^{22,36}$ Diagenetic precursors of $i-\mathrm{C}_{13}$ to $i-\mathrm{C}_{20}$ isoprenoids, such as aldehydes and ketones, ranging from $\mathrm{C}_{13}$ to $\mathrm{C}_{18}$, have been found in marine sediments and immature rock extracts. ${ }^{37,38}$ In the samples studied, these isoprenoids ranged from $i-\mathrm{C}_{14}$ to $i$ - $\mathrm{C}_{20}$ (Figure 3), thus suggesting the contribution of these organisms to the deposited OM.

Cycloalkanes (cyclohexanes) were identified by monitoring $m / z 82$ (Figure 4) in all samples, with a similar 

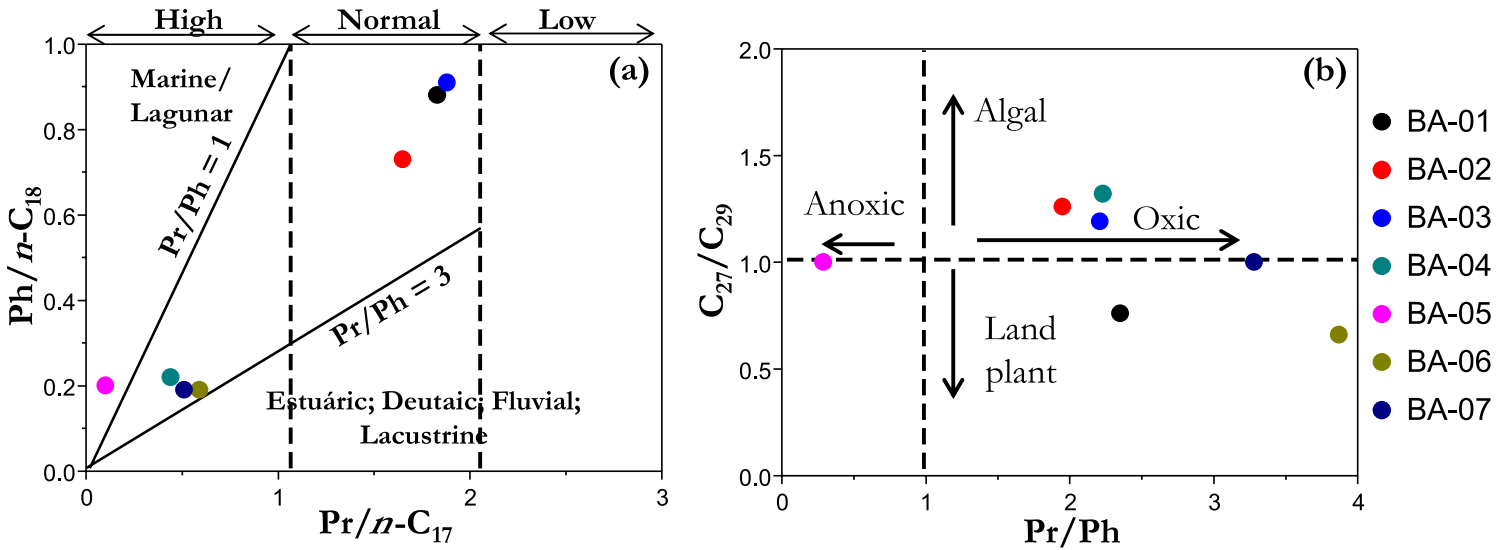

Figure 9. Graphs correlating the ratios: $\mathrm{Pr} / n-\mathrm{C}_{17} v s . \mathrm{Ph} / n-\mathrm{C}_{18}$ (a) and $\mathrm{Pr} / \mathrm{Ph} v s . \mathrm{C}_{27} / \mathrm{C}_{29}$ (b).

distribution to $n$-alkanes, with a predominance of structures with an odd number of carbon atoms, with a maximum in $\mathrm{C}_{17}$ and with decrease over the homologous series. A similar distribution has been identified in oil samples and rock extracts from the Ordovician and Devonian. ${ }^{39-43}$

High concentrations of cyclohexanes have been identified and associated with the presence of Gloeocapsomorpha prisca (G. prisca) algae in lower Devonian samples. ${ }^{40}$ These compounds have also been associated with cyclohexyl fatty acids isolated from bacteria, ${ }^{31,44}$ grown at high temperatures $\left(80{ }^{\circ} \mathrm{C}\right){ }^{45}$

Cycloalkanes of Silurian oils showed a maximum in $\mathrm{C}_{21}$, while in Ordovician and Devonian samples, they showed maximums in $\mathrm{C}_{17}$, indicating that these compounds are specific to precursor groups, differentiating between higher (Silurian) and plankton/microbial origin (Ordovician/ Devonian). ${ }^{42}$

The predominance of $\mathrm{C}_{27}$ steranes indicates mainly algal/planktonic OM entry, while the predominance of $\mathrm{C}_{29}$ steranes is associated with terrestrial plant $\mathrm{OM}$ entry. ${ }^{22,27,46-48}$ In the samples analyzed, $\mathrm{C}_{27}$ and $\mathrm{C}_{29}$ steranes are predominant over $\mathrm{C}_{28}$ (Table 3 ), reflecting a mixture in the contribution of marine and terrestrial origin, which can be seen in the ternary diagram (Figure 10). This relationship can be confirmed by the values of ratios $\mathrm{C}_{27} / \mathrm{C}_{29}$ and $\mathrm{C}_{28} / \mathrm{C}_{29}$ (Table 3).

Table 3. Parameters are calculated based on sterane distribution

\begin{tabular}{|c|c|c|c|c|c|c|c|}
\hline \multirow{2}{*}{ Parameter } & \multicolumn{7}{|c|}{ Sample } \\
\hline & BA-01 & BA-02 & BA-03 & BA-04 & BA-05 & BA-06 & BA-07 \\
\hline $\mathrm{C}_{27} \mathrm{a} / \%$ & 34.4 & 28.92 & 36.85 & 38.89 & 31.42 & 28.34 & 37.04 \\
\hline $\mathrm{C}_{28} \mathrm{~b} / \%$ & 30.44 & 40.6 & 30.42 & 31.87 & 34.44 & 37.51 & 29.54 \\
\hline $\mathrm{C}_{29}{ }^{\mathrm{c}} / \%$ & 37.42 & 30.48 & 32.73 & 30.2 & 34.14 & 34.15 & 33.42 \\
\hline Hop./Ste. ${ }^{d}$ & 4.81 & 8.22 & 9.17 & 51.35 & 42.84 & 45.58 & 35.72 \\
\hline $\mathrm{C}_{27} \alpha \beta \beta /(\alpha \beta \beta+\alpha \alpha \alpha)^{\mathrm{e}}$ & 0.33 & 0.88 & 0 & 0.12 & 0.71 & 0 & 0 \\
\hline $\mathrm{C}_{28} \alpha \beta \beta /(\alpha \beta \beta+\alpha \alpha \alpha)^{\mathrm{f}}$ & 0.49 & 0.47 & 0.34 & 0 & 0.67 & 0.47 & 0.83 \\
\hline$C_{29} \alpha \beta \beta /(\alpha \beta \beta+\alpha \alpha \alpha)^{g}$ & 0.67 & 0.55 & 0.38 & 0.61 & 0.40 & 0.42 & 0.58 \\
\hline $\mathrm{C}_{27} \alpha \alpha \alpha 20 R / \mathrm{C}_{29} \alpha \alpha \alpha 20 R^{\mathrm{h}}$ & 0.76 & 1.26 & 1.19 & 1.32 & 1.00 & 0.66 & 1.00 \\
\hline $\mathrm{C}_{28} \alpha \alpha \alpha 20 R / \mathrm{C}_{29} \alpha \alpha \alpha 20 R^{\mathrm{i}}$ & 0.31 & 0.34 & 0.41 & 0.52 & 0.62 & 0.77 & 0.29 \\
\hline $\mathrm{C}_{27} \alpha \beta \beta 20 S+R / \mathrm{C}_{29} \alpha \beta \beta 20 S+R^{\mathrm{j}}$ & 0.37 & 1.24 & 0.68 & 1.43 & 0.57 & 0.36 & 0.76 \\
\hline $\mathrm{C}_{28} \alpha \beta \beta 20 S+R / \mathrm{C}_{29} \alpha \beta \beta 20 S+R^{\mathrm{k}}$ & 0.31 & 0.28 & 0.30 & 0.19 & 0.35 & 0.34 & 0.35 \\
\hline$\left(\mathrm{C}_{27}\right.$ Reg + Dia $) /\left(\mathrm{C}_{29} \text { Reg }+ \text { Dia }\right)^{1}$ & 0.77 & 0.79 & 0.89 & 0.99 & 0.91 & 0.58 & 0.79 \\
\hline$\left(\mathrm{C}_{28} \operatorname{Reg}+\mathrm{Dia}\right) /\left(\mathrm{C}_{29} \mathrm{Reg}+\mathrm{Dia}\right)^{\mathrm{m}}$ & 0.33 & 0.24 & 0.39 & 0.38 & 0.59 & 0.53 & 0.36 \\
\hline $\mathrm{C}_{27} / \mathrm{C}_{29} \beta \alpha^{\mathrm{n}}$ & 0.77 & 0.72 & 0.75 & 0.93 & 0.96 & 0.76 & 0.75 \\
\hline $\mathrm{C}_{28} / \mathrm{C}_{29} \beta \alpha^{\circ}$ & 0.34 & 0.23 & 0.44 & 0.44 & 0.59 & 0.46 & 0.39 \\
\hline $\mathrm{C}_{27} \beta \alpha 20 S /(20 S+20 R)^{\mathrm{p}}$ & 0.60 & 0.57 & 0.50 & 0.57 & 0.59 & 0.61 & 0.59 \\
\hline $\mathrm{C}_{27} \beta \alpha \mathrm{Dia} /(\alpha \alpha \alpha+\alpha \beta \beta)^{\mathrm{q}}$ & 1.64 & 1.44 & 0.61 & 0.59 & 0.82 & 1.99 & 1.87 \\
\hline $\mathrm{C}_{28} \beta \alpha 20 S /(20 S+20 R)^{\mathrm{r}}$ & 0.59 & 0.78 & 0.42 & 0.65 & 0.59 & 0.59 & 0.58 \\
\hline
\end{tabular}


Table 3. Parameters are calculated based on sterane distribution (cont.)

\begin{tabular}{|c|c|c|c|c|c|c|c|}
\hline \multirow{2}{*}{ Parameter } & \multicolumn{7}{|c|}{ Sample } \\
\hline & BA-01 & BA-02 & BA-03 & BA-04 & BA-05 & BA-06 & BA-07 \\
\hline $\mathrm{C}_{28} \beta \alpha /(\alpha \alpha \alpha+\alpha \beta \beta)^{\mathrm{s}}$ & 1.87 & 1.68 & 0.98 & 0.88 & 0.71 & 1.01 & 2.71 \\
\hline $\mathrm{C}_{29} \beta \alpha 20 \mathrm{~S} /(20 S+20 R)^{\mathrm{t}}$ & 0.59 & 0.66 & 0.62 & 0.59 & 0.54 & 0.45 & 0.61 \\
\hline $\mathrm{C}_{29} \beta \alpha /(\alpha \alpha \alpha+\alpha \beta \beta)^{\mathrm{u}}$ & 1.62 & 2.50 & 0.82 & 0.81 & 0.72 & 1.27 & 2.17 \\
\hline$\Sigma$ Dia./ $/ \Sigma$ Ste. $^{v}$ & 0.77 & 0.85 & 0.75 & 0.54 & 0.35 & 0.49 & 0.36 \\
\hline iDiasterane $^{\mathrm{x}}$ & 87.19 & 98.16 & 95.81 & 97.83 & 77.84 & 90.58 & 92.54 \\
\hline Ratio TPP ${ }^{z}$ & 0.12 & 0.10 & 0.12 & 0.78 & 2.25 & 1.02 & 2.06 \\
\hline
\end{tabular}

${ }^{\mathrm{a}} \% \mathrm{C}_{27}=\left[\Sigma \% \mathrm{C}_{27} / \Sigma\left(\% \mathrm{C}_{27} \% \mathrm{C}_{29}\right)\right] \times 100 ;{ }^{\mathrm{b}} \% \mathrm{C}_{28}=\left[\Sigma \% \mathrm{C}_{28} / \Sigma\left(\% \mathrm{C}_{27}-\% \mathrm{C}_{29}\right)\right] \times 100 ;{ }^{\mathrm{c}} \% \mathrm{C}_{29}=\left[\Sigma \% \mathrm{C}_{29} / \Sigma\left(\% \mathrm{C}_{27}-\% \mathrm{C}_{29}\right)\right] \times 100 ;{ }^{\mathrm{d}} \mathrm{hopane} / \mathrm{sterane}$ (Hop./Ste.) $=\mathrm{C}_{30} 17 \alpha(\mathrm{H}), 21 \beta(\mathrm{H})$-hopane $/ \mathrm{C}_{27} 5 \alpha(\mathrm{H}), 14 \alpha(\mathrm{H}), 17 \alpha(\mathrm{H})$-cholestane $20 S ;{ }^{\mathrm{e}} \mathrm{C}_{27} \alpha \beta \beta /(\alpha \beta \beta+\alpha \alpha \alpha)=5 \alpha(\mathrm{H}), 14 \beta(\mathrm{H}), 17 \beta(\mathrm{H})-$ and $5 \alpha(\mathrm{H}), 14 \alpha(\mathrm{H}), 17 \alpha(\mathrm{H})$-cholestanes $20 R$ and $20 S ;{ }^{\mathrm{f}} \mathrm{C}_{28} \alpha \beta \beta /(\alpha \beta \beta+\alpha \alpha \alpha)=5 \alpha(\mathrm{H}), 14 \beta(\mathrm{H}), 17 \beta(\mathrm{H})-$ and $5 \alpha(\mathrm{H}), 14 \alpha(\mathrm{H}), 17 \alpha(\mathrm{H})-24-\mathrm{methylcholestanes}$ $20 R$ and $20 S ;{ }^{g} \mathrm{C}_{29} \alpha \beta \beta /(\alpha \beta \beta+\alpha \alpha \alpha)=5 \alpha(\mathrm{H}), 14 \beta(\mathrm{H}), 17 \beta(\mathrm{H})-$ and $5 \alpha(\mathrm{H}), 14 \alpha(\mathrm{H}), 17 \alpha(\mathrm{H})-24$-ethylcholestanes $20 R$ and $20 S ;{ }^{\mathrm{h}} \mathrm{C}_{27} \alpha \alpha \alpha R / \mathrm{C}_{29}$ $\alpha \alpha \alpha R=5 \alpha(\mathrm{H}), 14 \alpha(\mathrm{H}), 17 \alpha(\mathrm{H})$-cholestanes $20 R / 5 \alpha(\mathrm{H}), 14 \alpha(\mathrm{H}), 17 \alpha(\mathrm{H})$-24-ethylcholestane $20 R$; ${ }^{i} \mathrm{C}_{28} \alpha \alpha \alpha R / \mathrm{C}_{29} \alpha \alpha \alpha R=5 \alpha(\mathrm{H}), 14 \alpha(\mathrm{H}), 17 \alpha(\mathrm{H})-24-$ methylcholestanes $20 R / 5 \alpha(\mathrm{H}), 14 \alpha(\mathrm{H}), 17 \alpha(\mathrm{H})$-24-ethylcholestane $20 R ;{ }^{\mathrm{j}} \mathrm{C}_{27} \alpha \beta \beta S+R / \mathrm{C}_{29} \alpha \beta \beta S+R=5 \alpha(\mathrm{H}), 14 \alpha(\mathrm{H}), 17 \alpha(\mathrm{H})$-cholestanes $20 R$ and $20 S / 5 \alpha(\mathrm{H}), 14 \alpha(\mathrm{H}), 17 \alpha(\mathrm{H})-24-\mathrm{ethyl}-$ cholestanes $20 R$ and $20 S ;{ }^{k} C_{28} \alpha \beta \beta S+R / C_{29} \alpha \beta \beta S+R=5 \alpha(\mathrm{H}), 14 \alpha(\mathrm{H}), 17 \alpha(\mathrm{H})$-24-methylcholestanes $20 R$ and $20 S / 5 \alpha(\mathrm{H}), 14 \alpha(\mathrm{H}), 17 \alpha(\mathrm{H})-24-\mathrm{ethylcholestanes} 20 R$ and $20 S ;{ }^{1} \mathrm{C}_{27}(\mathrm{Reg}+\mathrm{Dia}) / \mathrm{C}_{29}(\mathrm{Reg}+\mathrm{Dia})=\Sigma(13 \beta(\mathrm{H}), 17 \alpha(\mathrm{H})-, 13 \alpha(\mathrm{H}), 17 \mathrm{a}(\mathrm{H})$-diacholestanes, $5 \alpha(\mathrm{H}), 14 \alpha(\mathrm{H}), 17 \alpha(\mathrm{H})-$ and $5 \alpha(\mathrm{H}), 14 \beta(\mathrm{H}), 17 \beta(\mathrm{H})-\mathrm{cholestane} 20 R$ and $20 S) / \Sigma\left(13 \beta(\mathrm{H}), 17 \alpha(\mathrm{H})-, 13 \alpha(\mathrm{H}), 17 \alpha(\mathrm{H})-24\right.$-ethyldiacholestanes, $5 \alpha(\mathrm{H}), 14 \alpha(\mathrm{H}), 17 \alpha(\mathrm{H})-$ and $5 \alpha(\mathrm{H}), 14 \beta(\mathrm{H}), 17 \beta(\mathrm{H})-24-$ ethylcholestane $20 R$ and $20 S$; ${ }^{\mathrm{m}} \mathrm{C}_{28}(\mathrm{regular}$ sterane + diasterane $) / \mathrm{C}_{29}($ regular sterane + diasterane $)\left(\mathrm{C}_{28}(\mathrm{Reg}+\mathrm{Dia}) / \mathrm{C}_{29}(\mathrm{Reg}+\mathrm{Dia})\right)=\Sigma(13 \beta(\mathrm{H}), 17 \alpha(\mathrm{H})-24-\mathrm{methyl}, 13 \alpha(\mathrm{H}), 17 \alpha(\mathrm{H})-24-\mathrm{methyldiacholestanes}$, $5 \alpha(\mathrm{H}), 14 \alpha(\mathrm{H}), 17 \alpha(\mathrm{H})$ - and $5 \alpha(\mathrm{H}), 14 \beta(\mathrm{H}), 17 \beta(\mathrm{H})-24-$ metilcolestano $20 R$ and $20 S) / \Sigma(13 \beta(\mathrm{H}), 17 \alpha(\mathrm{H})-, 13 \alpha(\mathrm{H}), 17 \alpha(\mathrm{H})-24-\mathrm{ethyldiacholestanes}, 5 \alpha(\mathrm{H}), 14 \alpha(\mathrm{H}), 17 \alpha(\mathrm{H})-$ and $5 \alpha(\mathrm{H}), 14 \beta(\mathrm{H}), 17 \beta(\mathrm{H})$ - 24-ethylcholestane $20 R$ and $20 S ;{ }^{n} \mathrm{C}_{27} / \mathrm{C}_{29} \beta \alpha=13 \beta(\mathrm{H}), 17 \alpha(\mathrm{H})$-diacholestanes $20 R$ and $20 S / 13 \beta(\mathrm{H}), 17 \alpha(\mathrm{H})-24-\mathrm{ethyldiacholestanes} 20 R$ and $20 S ;{ }^{\circ} \mathrm{C}_{28} / \mathrm{C}_{29} \beta \alpha=13 \alpha(\mathrm{H}), 17 \alpha(\mathrm{H})-24$-methyldiacholestanes $20 R$ and $20 S / 13 \beta(\mathrm{H}), 17 \alpha(\mathrm{H})$-24-ethyldiacholestanes $20 R$ and $20 S ;{ }^{\mathrm{P}} \mathrm{C}_{27} \beta \alpha S /(20 S+20 R)=13 \alpha(\mathrm{H}), 17 \alpha(\mathrm{H})-$ diacholestanes $20 R$ and $20 S ;{ }^{9} \mathrm{C}_{27} \beta \alpha /(\alpha \alpha \alpha+\alpha \beta \beta)=13 \beta(\mathrm{H}), 17 \alpha(\mathrm{H})$-diacholestanes $20 R$ and $20 S / 5 \alpha(\mathrm{H}), 14 \beta(\mathrm{H}), 17 \beta(\mathrm{H})-$ and $5 \alpha(\mathrm{H}), 14 \alpha(\mathrm{H}), 17 \alpha(\mathrm{H})$-cholestanes $20 R$ and $20 S ;{ }^{\mathrm{r}} \mathrm{C}_{28} \beta \alpha \mathrm{S} /(20 S+20 R)=13 \alpha(\mathrm{H}), 17 \alpha(\mathrm{H})-24$-methyldiacholestanes $20 R$ and $20 S ;{ }^{\mathrm{s}} \mathrm{C}_{28} \beta \alpha /(\alpha \alpha \alpha+\alpha \beta \beta)=13 \alpha(\mathrm{H}), 17 \alpha(\mathrm{H})-24-\mathrm{methyldiacholestanes} 20 R$ and $20 S / 5 \alpha(\mathrm{H}), 14 \beta(\mathrm{H}), 17 \beta(\mathrm{H})-$ and $5 \alpha(\mathrm{H}), 14 \alpha(\mathrm{H}), 17 \alpha(\mathrm{H})$-24-methylcholestanes $20 R$ and $20 S$; ${ }^{\mathrm{t}} \mathrm{C}_{29} \beta \alpha \mathrm{S} /(20 \mathrm{~S}+20 R)=13 \alpha(\mathrm{H}), 17 \alpha(\mathrm{H})-24$-ethyldiacholestanes $20 R$ and $20 S$; " $\mathrm{C}_{29} \beta \alpha /(\alpha \alpha \alpha+\alpha \beta \beta)=13 \alpha(\mathrm{H}), 17 \alpha(\mathrm{H})$-24-ethyldiacholestanes $20 R$ and $20 S / 5 \alpha(\mathrm{H}), 14 \beta(\mathrm{H}), 17 \beta(\mathrm{H})-$ and $5 \alpha(\mathrm{H}), 14 \alpha(\mathrm{H}), 17 \alpha(\mathrm{H})-24-\mathrm{ethylcholestanes} 20 R$ and $20 S$; ${ }^{v} \Sigma \mathrm{Dia} / \Sigma$ Ste $=13 \beta(\mathrm{H}), 17 \alpha(\mathrm{H})$-diacholestane $20 R / 5 \alpha(\mathrm{H}), 14 \alpha(\mathrm{H}), 17 \alpha(\mathrm{H})$-cholestanes $20 R$ and $20 S ;{ }^{\mathrm{i}} \mathrm{Diasterane}=\left[13 \mathrm{~b}(\mathrm{H}), 17 \mathrm{a}(\mathrm{H}) 20(S+R)-\mathrm{C}_{27} \mathrm{diasteranes}\right] /$ $\left[13 \mathrm{~b}(\mathrm{H}), 17 \mathrm{a}(\mathrm{H}) 20(S+R)-\mathrm{C}_{27}\right.$ diasteranes + aaa20 $(S+R)-\mathrm{C}_{29}$ sterane $]$; ${ }^{7}$ ratio TPP $=\mathrm{TPP}(\mathrm{Ta}+\mathrm{Tb}) / 13 \beta(\mathrm{H}), 17 \alpha(\mathrm{H})$-diacholestane $20 R$ and $20 S .{ }^{49} \mathrm{TPP}$ : tetracyclic polyprenoid.

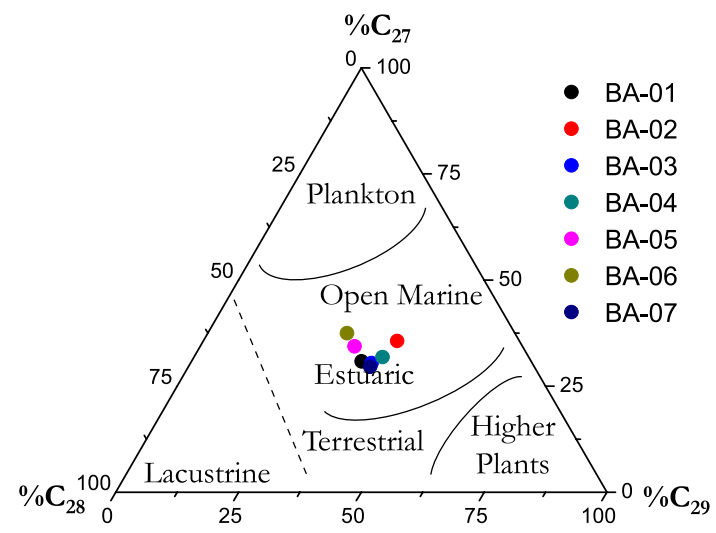

Figure 10. Ternary graph showing the relationship between the steranes $\left(\mathrm{C}_{27}, \mathrm{C}_{28}\right.$, and $\left.\mathrm{C}_{29}\right)$, showing the composition and source of the organic matter of the samples.

In general, samples with high hopane concentrations and high Hop./Ste. (> 7) are indicative of reworked and/ or terrestrial lake-type OM. ${ }^{22,50-52}$ The upper Devonian outcrop samples of the present study have high hopane concentrations (Table S2, SI section) and for this ratio (Hop./Ste.) the values found are greater than 7, except for sample BA-01, suggesting a continuous fluvial influx of continental OM (Table 4).

Bicyclic sesquiterpenoids have been identified and the typical distribution is shown in Figure 6. These compounds are widely found among the constituents of higher plant essential oils and resins, but there are reports of their identification in marine organisms such as brown algae ${ }^{53,54}$ Protosalvinia plant fossils have been identified in samples from the Uraiá Member, which corresponds to the top of the Barreirinha Formation, ${ }^{12}$ and in recent studies, after extraction and analysis of the aliphatic fraction of Protosalvinia fossils, it was possible to identify this bicyclic sesquiterpenoids. ${ }^{15}$

Tricyclic terpanes have also been identified in low abundance. Tricyclic terpanes are believed to originate from tricyclohexaprenol, which is a constituent of cell membranes of prokaryotes, but large quantities of these compounds have been identified in rocks rich in tasmanites, and their origin from primitive algae may be suggested. ${ }^{29,34,55-57}$ High ratios of $\mathrm{C}_{21} / \mathrm{C}_{23}(>1)$ tricyclic terpanes are indicative of terrestrial $\mathrm{OM}$ and low ratios $(<1)$ are indicative of marine OM..$^{29,34,56}$ For the studied samples, it is possible to suggest a mixture of both types of contributions (Table 4).

\section{Depositional environment and redox conditions}

High sulfur values (Table 1) suggest a marine deposition environment, but organic geochemical indicators do 
Table 4. Parameters calculated based on the distribution of tri- and pentacyclic terpanes

\begin{tabular}{|c|c|c|c|c|c|c|c|}
\hline \multirow{2}{*}{ Parameter } & \multicolumn{7}{|c|}{ Sample } \\
\hline & BA-01 & BA-02 & BA-03 & BA-04 & BA-05 & BA-06 & BA-07 \\
\hline $\mathrm{C}_{20} / \mathrm{C}_{21} \mathrm{Tri}^{\mathrm{a}}$ & 0.73 & nd & 0.61 & 1.09 & 1.34 & nd & 1.35 \\
\hline $\mathrm{C}_{21} / \mathrm{C}_{23}$ Tri $^{\mathrm{b}}$ & nd & nd & 0.57 & 1.54 & 2.12 & nd & 3.11 \\
\hline $\mathrm{C}_{23}$ Tri $/ \mathrm{C}_{30} \mathrm{H}^{\mathrm{c}}$ & nd & nd & 0.05 & 0.02 & 0.01 & nd & 0.01 \\
\hline $\mathrm{iTri}^{\mathrm{d}}$ & 11.52 & 3.27 & 13.90 & 12.86 & 8.63 & 3.79 & 10.44 \\
\hline$\alpha \beta_{31} / \alpha \beta C_{30}{ }^{e}$ & 0.39 & 0.40 & 0.38 & 0.26 & 0.30 & 0.26 & 0.17 \\
\hline$\alpha \beta S_{31} / S+R^{\mathrm{f}}$ & 0.56 & 0.55 & 0.57 & 0.55 & 0.53 & 0.55 & 0.66 \\
\hline$\alpha \beta S_{32} / S+R^{g}$ & 0.59 & 0.57 & 0.52 & 0.54 & 0.51 & 0.50 & 0.63 \\
\hline$\alpha \beta S_{33} / S+R^{\mathrm{h}}$ & 0.61 & 0.55 & 0.59 & 0.55 & 0.53 & 0.53 & 0.31 \\
\hline$\alpha \beta S_{34} / S+R^{\mathrm{i}}$ & 0.59 & nd & 0.34 & 0.36 & 0.45 & 0.35 & 0.06 \\
\hline$\alpha \beta S_{35} / S+R^{\mathrm{j}}$ & nd & nd & 0.63 & 0.70 & $\mathrm{nd}$ & nd & nd \\
\hline $\mathrm{Ts}_{27} / \mathrm{Tm}_{27}{ }^{\mathrm{k}}$ & 0.19 & 0.20 & 0.19 & 0.45 & 0.35 & 0.32 & 0.27 \\
\hline $\mathrm{Ts}_{27} /\left(\mathrm{Ts}_{27}+\mathrm{Tm}_{27}\right)^{1}$ & 0.16 & 0.16 & 0.16 & 0.31 & 0.26 & 0.24 & 0.21 \\
\hline${ }_{29} \mathrm{Ts} / \alpha \beta S_{30}{ }^{\mathrm{m}}$ & 0.11 & 0.10 & 0.11 & 0.12 & 0.13 & 0.14 & 0.13 \\
\hline $\mathrm{Ts}_{29} /\left(\mathrm{Ts}_{29}+\alpha \beta_{29}\right)^{\mathrm{n}}$ & 0.13 & 0.18 & 0.21 & 0.17 & 0.34 & 0.23 & 0.20 \\
\hline$\alpha \beta S 34 / \alpha \beta S 35^{\circ}$ & nd & nd & 1.95 & 1.64 & $\mathrm{nd}$ & 3.25 & 3.45 \\
\hline$\alpha \beta 29 / \alpha \beta 30^{\mathrm{p}}$ & 0.77 & 0.77 & 0.67 & 0.56 & 0.71 & 0.69 & 0.72 \\
\hline$\beta \alpha 29 / \alpha \beta 29^{q}$ & 0.35 & 0.28 & 0.40 & 0.36 & 0.35 & 0.38 & 0.39 \\
\hline $30 \mathrm{D} / \alpha \beta 30^{\mathrm{r}}$ & 0.10 & 0.06 & 0.10 & 0.08 & 0.06 & 0.06 & 0.03 \\
\hline$\beta \alpha 30 / \alpha \beta 30^{\mathrm{s}}$ & 0.30 & 0.08 & 0.20 & 0.08 & 0.11 & 0.04 & 0.03 \\
\hline$\alpha \beta 30 /(\alpha \beta 31-\alpha \beta 35)^{t}$ & 0.59 & 0.71 & 0.49 & 1.27 & 0.93 & 0.92 & 1.00 \\
\hline
\end{tabular}

${ }^{a} \mathrm{C}_{20} / \mathrm{C}_{21}$ Tri $=\mathrm{C}_{20} / \mathrm{C}_{21}$ tricyclic terpanes; ${ }^{\mathrm{b}} \mathrm{C}_{21} / \mathrm{C}_{23}$ Tri $=\mathrm{C}_{20} / \mathrm{C}_{21}$ tricyclic terpanes; ${ }^{\mathrm{c}} \mathrm{C}_{23}$ Tri/C30H $=\mathrm{C}_{23}$ tricyclic terpane/ $\mathrm{C}_{30} 17 \alpha(\mathrm{H}), 21 \beta(\mathrm{H})$-hopane; ${ }^{\mathrm{d}}$ tricyclic index $=100 \times \Sigma \mathrm{C}_{19}-\mathrm{C}_{29}$ (except $\mathrm{C}_{22}$ and $\mathrm{C}_{27}$ ) terpanes tricyclics $/ \mathrm{C}_{30} 17 \alpha(\mathrm{H}), 21 \beta(\mathrm{H})$-hopane; ${ }^{51}{ }^{\mathrm{e}} \alpha \beta 31 / \alpha \beta C 30=\mathrm{C}_{31} 17 \alpha(\mathrm{H}), 21 \beta(\mathrm{H})$-homohopane/C $\mathrm{C}_{30}$ $17 \alpha(\mathrm{H}), 21 \beta(\mathrm{H})$-hopane; $\mathrm{f}_{31} \alpha \beta \mathrm{S} / S+R=22 S /(22 S+22 R) \mathrm{C}_{31} 17 \alpha(\mathrm{H}), 21 \beta(\mathrm{H})$-homohopane; ${ }^{\mathrm{g}} \mathrm{C}_{32} \alpha \beta \mathrm{S} / S+R=22 S /(22 S+22 R) \mathrm{C}_{32} 17 \alpha(\mathrm{H}), 21 \beta(\mathrm{H})-\mathrm{bis}-$ homohopane; ${ }^{\mathrm{h}} \mathrm{C}_{33} \alpha \beta \mathrm{S} / S+R=22 \mathrm{~S} /(22 \mathrm{~S}+22 R) \mathrm{C}_{33} 17 \alpha(\mathrm{H}), 21 \beta(\mathrm{H})$-trishomohopane; ${ }^{i} \mathrm{C}_{34} \alpha \beta \mathrm{S} / S+R=22 S /(22 S+22 \mathrm{R}) \mathrm{C}_{34} 17 \alpha(\mathrm{H}), 21 \beta(\mathrm{H})$-tetrahomohopane; ${ }^{\mathrm{j}} \mathrm{C}_{35} \alpha \beta \mathrm{S} / S+R=22 S /(22 S+22 R) \mathrm{C}_{35} 17 \alpha(\mathrm{H}), 21 \beta(\mathrm{H})$-pentahomohopane; ${ }^{k} \mathrm{Ts} 27 / \mathrm{Tm} 27=\mathrm{C}_{27} 18 \alpha(\mathrm{H})-22,29,30$-trisnorneohopane/C $2717 \alpha(\mathrm{H})-22,29,30$-trisnorhopane; ${ }^{1} \mathrm{Ts} 27 /(\mathrm{Ts} 27+\mathrm{Tm} 27)=\mathrm{C}_{27} 18 \alpha(\mathrm{H})-22,29,30$-trisnorneohopane $/ \mathrm{C}_{27} 18 \alpha(\mathrm{H})-22,29,30$-trisnorneohopane $+\mathrm{C}_{27} 17 \alpha(\mathrm{H})-22,29,30$-trisnorhopane; ${ }^{2} 29 \mathrm{Ts} / \alpha \beta \mathrm{S} 30=\mathrm{C}_{27}$ $18 \alpha(\mathrm{H})-22,29,30$-trisnorneohopane $/ \mathrm{C}_{30} 17 \alpha(\mathrm{H}) / 21 \beta(\mathrm{H})$-hopane; ${ }^{\mathrm{n} T s} 29 /(\mathrm{Ts} 29+\alpha \beta 29)=\mathrm{C}_{29} 18 \alpha(\mathrm{H})-22,29,30$-norneohopane/(C 29 18 $\alpha(\mathrm{H})-22,29,30$-norneohopane + $\mathrm{C}_{29} 18 \alpha(\mathrm{H})-22,29,30$-norhopane; ${ }^{\circ} \alpha \beta S 34 / \alpha \beta S 35=\mathrm{C}_{34} 17 \alpha(\mathrm{H}), 21 \beta(\mathrm{H})$-tetrahomohopane $/ \mathrm{C}_{35} 17 \alpha(\mathrm{H}), 21 \beta(\mathrm{H})$-pentahomohopane; ${ }^{\mathrm{p}} \alpha \beta 29 / \alpha \beta 30=\mathrm{C}_{29} 17 \alpha(\mathrm{H}), 21 \beta(\mathrm{H})-$ norhopano/ $\mathrm{C}_{30} 17 \alpha(\mathrm{H}), 21 \beta(\mathrm{H})$-hopane; ${ }^{9} \beta \alpha 29 / \alpha \beta 29=\mathrm{C}_{29} 17 \beta(\mathrm{H}), 21 \alpha(\mathrm{H})$-hopane $/ \mathrm{C}_{29} 17 \alpha(\mathrm{H}), 21 \beta(\mathrm{H})$-norhopane; ${ }^{\mathrm{r}} 30 \mathrm{D} / \alpha \beta 30=\mathrm{C}_{30}$ diahopane $/ \mathrm{C}_{30} 17 \alpha(\mathrm{H}), 21 \beta(\mathrm{H})$ hopane; ${ }^{s} \beta \alpha 30 / \alpha \beta 30=\mathrm{C}_{29} 17 \beta(\mathrm{H}), 21 \alpha(\mathrm{H})$-hopane $/ \mathrm{C}_{30} 17 \alpha(\mathrm{H}), 21 \beta(\mathrm{H})$-hopane; ${ }^{\mathrm{t}} \alpha \beta 30 /(\alpha \beta 31-\alpha \beta 35)=\mathrm{C}_{30} 17 \alpha(\mathrm{H}), 21 \beta(\mathrm{H})$-hopane $/ \Sigma$ homohopanes $\left(\mathrm{C}_{31}-\mathrm{C}_{35}\right)$; nd: not detected.

not show hypersalinity characteristics for the studied samples. ${ }^{46,58}$ Barreirinha Formation has high OM content preserved as a result of high anoxia conditions during deposition flood events, ${ }^{59}$ suggesting an anoxic sea. ${ }^{3,12,15}$

$\mathrm{The} \mathrm{Pr} / \mathrm{Ph}$ ratio is indicative of the redox conditions under which the OM was being deposited. ${ }^{60}$ Low values $(<1)$ are indicative of anoxic depositional environment, intermediate values $(1<\mathrm{Pr} / \mathrm{Ph}<3)$ are indicative of suboxic conditions and high values $(>3)$ suggest toxic environment. ${ }^{22,27,61}$ For samples analyzed (Table 2), these values suggest a suboxic to toxic sedimentation environment.

Moreover, these values when compared $n$-alkanes and isoprenoids $\left(\mathrm{Pr} / \mathrm{C}_{17}\right.$ and $\mathrm{Ph} / \mathrm{C}_{18}$ ratios, Table 3), indicate marine $\mathrm{OM}$, preserved under suboxic to anoxic conditions $^{22,60}$ and also suggest marine depositional environment, with low terrestrial OM deposition ${ }^{46}$ and for the $\mathrm{P} / \mathrm{C}_{17} v s . \mathrm{Ph} / \mathrm{C}_{18}$ cross-relation (Figure $9 \mathrm{a}$ ) ranged from anoxic/non-oxic to sub-oxic/oxic, suggesting deposition in distal marine environment, continental shelf, and delta environment for more oxides.
The $i$ - $\mathrm{C}_{15}$ isoprenoid (farnesane), as already mentioned, is a lateral constituent of bacteriochlorophylls, biosynthesized by organisms of the Chlorobiaceae family. Since these organisms live only in the euxinic photic zone, that is, they need light and hydrogen sulfide $\left(\mathrm{H}_{2} \mathrm{~S}\right)$ to obtain their food (photosynthesis), ${ }^{22,36,62}$ it is possible to suggest, for the studied samples (Figure 4) this paleoenvironmental sedimentation condition.

The ratio $\Sigma$ Dia./ $/ \Sigma$ Ste. is generally used as a maturation parameter. ${ }^{63-66}$ However, previous studies ${ }^{67,68}$ have indicated that acidic (presence of clay minerals) or strongly oxidizing conditions catalyze conversion reactions from regular steranes to diasteranes, being related to deltaic marine deposition environments. In oil samples from evaporative carbonate or marine sources, diasteranes are in low relative abundance or even absent. ${ }^{51}$ For the samples studied, this parameter ranged from $0.35-0.85$ (Table 3 ), indicating siliciclastic rocks. ${ }^{51,68,69}$

Values above 1.0 for parameter $\alpha \beta 29 / \alpha \beta 30$ are typically indicators of deposition of anoxic carbonate rocks. ${ }^{22}$ In this 
study, values ranged from 0.56 to 0.77 (Table 4), which are associated with clay-rich marine rocks. ${ }^{70,71}$ The high abundance of $\mathrm{C}_{35}$ homohopanes is indicative of reducing depositional conditions. High values of the parameter $\alpha \beta S 34 / \alpha \beta 35$ (> 1, Table 4) suggest suboxic to anoxic environment. ${ }^{47,72}$ Unlike lake rocks, marine rocks have high values (>0.25) for the $\alpha \beta S 31 / \alpha \beta 30$ ratio and can be used to distinguish marine from lake environments. ${ }^{22,57}$ The samples presented high values, ranging from 0.26-0.40, thus suggesting a marine environment, except for the BA-07 sample (Table 4).

The studied samples showed an increasing bottom-totop concentration of $\mathrm{C}_{30} \mathrm{Ta}$ and $\mathrm{Tb}$ tetracyclic polyprenoids (Figure 11, TPP 25, Figure S4, SI section). When present in considerable abundance these compounds suggest a contribution of freshwater OM (algae) with low salinity for the studied samples. The occurrence in the Barreirinha Formation is the signature of terrestrial organic matter contribution due to constant fluvial inflow into the marine realm (Figure 11, Table 3). ${ }^{49,51,73,74}$ which is indicated by the high Hop./Ste. and TPP ratio (Table 3).

An indicator of the marine sedimentation environment is the presence of regular $\mathrm{C}_{30}$ or 24-n-propylcholestane $\left(\mathrm{C}_{30}-\mathrm{npc}\right)$. This biomarker has as precursor 24-n-propylcholestanol, which is present in chrysophyte algae of the order Sarcinochrysidales. $\mathrm{C}_{30}$-npc precursors have been identified in 24-n-propylidene-cholesterol and $24-n$-propylcholesterol ${ }^{75}$ in pellagophyte microalgae. A small class of seaweed (Pelagophyceae) also synthesizes one of the precursors of $\mathrm{C}_{30}$-npc, 24(E)-24-propylidene-cholesterol. ${ }^{76,77}$ Thus, the presence of $\mathrm{C}_{30}$-npc is taken as evidence of the contribution and environment of marine sedimentation.
In the studied samples, to confirm the presence of this compound $\left(\mathrm{C}_{30}-\mathrm{npc}\right)$, a synthetic pattern co-injection of this biomarker was performed. The sample BA-01 was selected because it presented a higher relative abundance of $\mathrm{C}_{30}-\mathrm{npc}$ among the studied samples. Figure 12 presents the GC-MS/MS experiment, showing the presence of this biomarker.

\section{Thermal evolution}

In general, thermally immature rocks have $\mathrm{T}_{\max }$ values (peak temperature of pyrolysis) $<435-440{ }^{\circ} \mathrm{C}$ and $\mathrm{PI}<0.1$ whereas those that have reached the peak of generation have $\mathrm{T}_{\max }$ values between $445-450{ }^{\circ} \mathrm{C}$ and PI of the order $0.4 .{ }^{16}$ Thus, the values for the samples under study (Table 1) suggest that they are thermally immature.

The CPI values found for the samples (> 1, Table 2) suggest low maturity of the studied samples, except for sample BA-02, which had a value slightly lower than 1 $(\mathrm{CPI}=0.97){ }^{78,79}$ The parameters Ts27/Tm27, Ts27/ $($ Ts27 + Tm27), Ts27/ $\alpha \beta 30$ and Ts29/(Ts29+ $\alpha \beta 29)$ (Table 3) present low values $(<1)$ suggesting the low thermal evolution of the samples. . $^{51,63,70,71,80,81}$

The ratios of homohopanes $(\mathrm{HH}) 22 S /(22 S+22 R)$ have their equilibrium established between 0.57-0.62. In general, this parameter is applied to homohopanes $\alpha \beta 31$ and/or $\alpha \beta 32$, since this parameter can be influenced by co-elution of other compounds. The samples presented values that ranged between $0.53-0.66 ; 0.50-0.63 ; 0.31-0.61$; $0.06-0.59$ and 0.63-0.70 for homohopanes $\alpha \beta 31, \alpha \beta 32$, $\alpha \beta 33, \alpha \beta 34$, and $\alpha \beta 35$, respectively. These values reflect the low maturity, except for samples BA-03 and BA-04 which were the only ones that could be calculated for $\alpha \beta 31$.

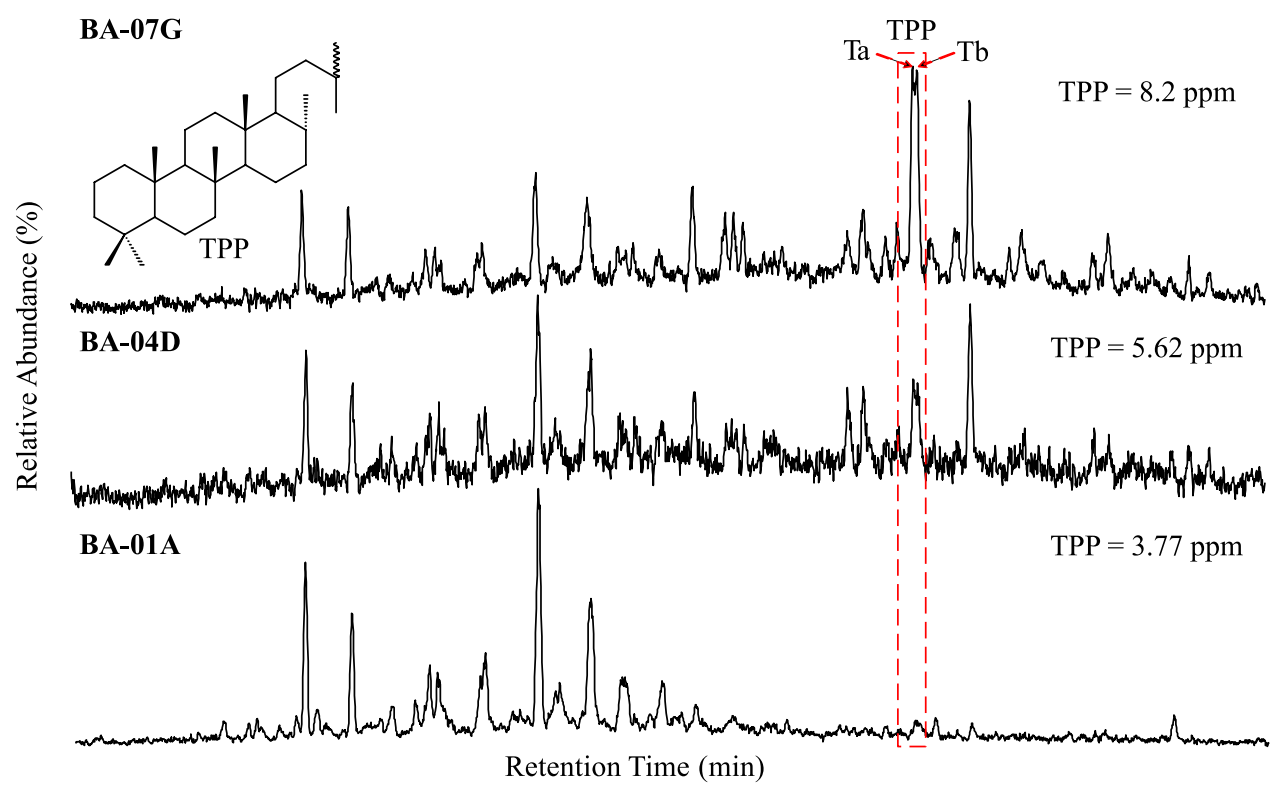

Figure 11. RIC $m / z 259$ showing the distribution of TPP's in the samples corresponding to the bottom, middle, and top. 


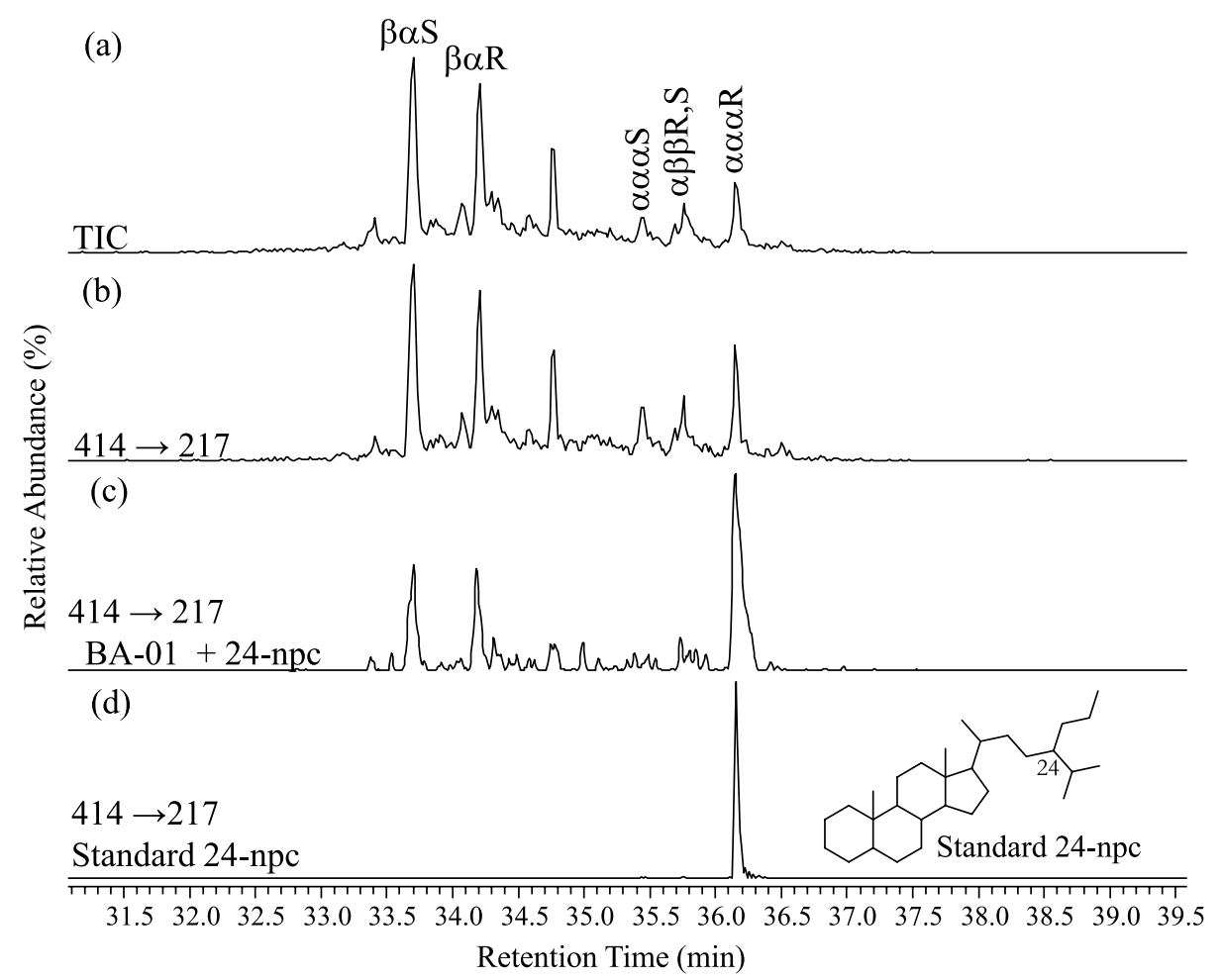

Figure 12. Characteristic multiple reaction monitoring (MRM) chromatogram of $\mathrm{C}_{30}$ steranes found in the samples. Total ion chromatogram (a) $\mathrm{M}^{+*} 414 \rightarrow m / z 217$ transition, (b) $\mathrm{M}^{+} 414 \rightarrow m / z 217$ transitions of BA-01 sample co-injected with 24-npc standard ( $0.5 \mathrm{ppm}$ ), and (c) $\mathrm{M}^{+*} 414 \rightarrow m / z 217$ transition from the 24-npc standard.

The morethane/hopane $\beta \alpha 29 / \alpha \beta 29$ and $\beta \alpha 30 / \alpha \beta 30$ ratios corroborate the immaturity suggestion of the samples since their calculated values (Table 4) are in the range of $0.8-0.35 .^{22}$ The isomerization of steranes $\beta \beta /(\beta \beta+\alpha \alpha)$ and $20 S /(20 S+20 R)$ are other parameters of maturation. For the samples studied, both parameters were calculated for the $\mathrm{C}_{27}$ and $\mathrm{C}_{29}$ steranes (Table 3 ) and their values ranged from 0.12-0.88 to 0.38-0.67 $\left(\mathrm{C}_{27}\right.$ and $\left.\mathrm{C}_{29} \beta \beta /(\beta \beta+\alpha \alpha)\right)$ and 0.18-0.58 and 0.23-0.72 $\left(\mathrm{C}_{27}\right.$ and $\left.\mathrm{C}_{29} 20 S /(20 S+20 R)\right)$, indicating immaturity of $\mathrm{OM}$.

\section{Conclusions}

Rock-Eval results suggested that the samples analyzed have $\mathrm{T}_{\max }$ values typically below $440{ }^{\circ} \mathrm{C}$ and are therefore thermally immature. The studied fractions showed a bimodal distribution of $n$-alkanes from $n$ - $\mathrm{C}_{12}$ to $n$ - $\mathrm{C}_{36}$, suggesting a mixed contribution of organic matter (marine and continental). The most frequently used biomarker parameters to assess maturity such as hopane $\mathrm{C}_{31}-22 S / 22 S+22 R$, sterane $\mathrm{C}_{29}-20 \mathrm{~S} / 20 \mathrm{~S}+20 R$ and trisnorhopane, Ts $/ \mathrm{Ts}+\mathrm{Tm}, \mathrm{CPI}$, and $\mathrm{Pr} / \mathrm{Ph}$ ratios were consistent with the data from Rock-Eval, suggesting thermally immature samples, however, these data and those referring to the (marine) origin of the samples should be viewed with caution as they are outcrop samples subject to recent changes or contamination.
The high abundance of the Hop./Ste. ratio, the absence or low relative abundance of $\beta$-carotane and gammacerane may be due to the low salinity as well as the presence of oxygen in this depositional environment, suggests a continuous fluvial influx of continental OM, corroborated by the increasing presence of TPP from the base to the top of the studied samples. In general, the samples presented different geochemical characteristics among themselves, varying composition and abundance of the studied compounds (linear and isoprenoid alkanes, tri- and pentacyclic terpanes, steranes, and tetracyclic polyprenoids). The parameters agree as to the immaturity of the samples, the mixture in the contribution of the deposited organic matter, differences in salinity, and sediment deposition.

\section{Supplementary Information}

Supplementary data (quantification data, GC-MS/MS MRM representative of the series of hopanos identified in the studied samples (BA-01) and GC-MS/MS MRM representative of the series of tetracyclic steroids and polyprenoids (TPP's) identified in the studied samples (BA-07, rich in TPP's)) are available free of charge at http:// jbcs.sbq.org.br as PDF file. 


\section{Acknowledgments}

The authors would like to thank CAPES and FAPEPI for the financial contribution and to Prof Francisco Reis (UNICAMP) for the kind concession of the 24-n-propyl cholestane standard.

\section{Author Contributions}

Andrenilton F. Silva was responsible for investigation, methodology, writing-original draft; Artur L. C. Barros for investigation, methodology, writing-original draft; Alek A. C. Sousa for methodology; Daniel M. Jarvie for writing-review and editing; Sebastian M. Calderón for investigation, methodology, writingoriginal draft; Ailton S. Brito for writing-review and editing; Afonso C. R. Nogueira for conceptualization, investigation, supervision, writing-review and editing; Alexandre A. de Souza was responsible for writing-review and editing; Sidney G. de Lima for conceptualization, investigation, supervision, project administration, writing-review and editing.

\section{References}

1. de Almeida, F. F. M.; Carneiro, C. D. R. In Geologia do Continente Sul-Americano: Evolução da Obra Fernando Flávio Marques Almeida, $1^{\text {st }}$ ed.; Mantesso-Neto, V.; Bartorelli, A.; Carneiro, C. D. R.; de Brito-Neves, B. B., eds.; Beca: Brazil, 2004, p. 43.

2. Caputo, M. V.; Palaeogeogr., Palaeoclimatol., Palaeoecol. 1985, 51,291

3. Cunha, P. R.; Gonzaga, F. G.; Coutinho, L. F. C.; Feijó, F. J.; Bol. Geocienc. Petrobrás 1994, 8, 47.

4. Cunha, P. R.: Análise Estratigráfica dos Sedimentos Eo/ Mesodevonianos da Porção Ocidental da Bacia do Amazonas sob a Ótica da Estratigrafia de Sequências no Interior Cratônico; MSc Dissertation, Universidade Federal do Rio Grande do Sul, Porto Alegre, Brazil, 2000, available at https:// lume.ufrgs.br/handle/10183/2657, accessed in November 2021.

5. Calderón, S. M.: Geoquímica Orgânica da Formação Barreirinha, Devoniano Superior da Bacia do Amazonas, Município de Rurópolis, Pa: Implicações Paleoambientais e Avaliação do Potencial Gerador de Hidrocarbonetos; MSc Dissertation, Universidade Federal do Pará, Belém, Brazil, 2017, available at https://www.ppgg.propesp.ufpa.br/ ARQUIVOS/dissertacoes/2017_dissertacao_Sebastian_Molina. pdf, accessed in November 2021.

6. Milani, E. J.; Zalán, P. V.; Episodes 1999, 22, 199.

7. Cunha, P. R. C.; de Melo, J. H. G.; da Silva, O. B.; Bol. Geocienc. Petrobrás 2007, 15, 227.

8. Alberto, C.; Neves, O.; Bol. Geocienc. Petrobrás 1990, 4, 95.

9. Loboziak, S.; Melo, J. H. G.; Rodrigues, R.; Streel, M.; Quadros,
L. P.; Barrilari, I. M. R.; An. Acad. Bras. Cienc. 1996, 68, 206.

10. Grahn, Y.; de Melo, J. H. G.; Bull. Geosci. 2003, 78, 373.

11. Melo, J. H. G.; Loboziak, S.; Rev. Palaeobot. Palynol. 2003, 124, 131.

12. Cardoso, C. N.; Sanz-López, J.; Blanco-Ferrera, S.; Lemos, V. B.; Scomazzon, A. K.; Palaeogeogr., Palaeoclimatol., Palaeoecol. 2015, 418, 57.

13. Gonzaga, F. G.; Coutinho, L. C.; Gonçlves, F. T. T. In Petroleum Systems of South Atlantic Margins, vol. 73; Mello, M. R.; Katz, B. J., eds.; American Association of Petroleum Geologists, 2000, p. 159.

14. Garcia, P. H. V.: Geoquímica Orgânica das Formações Ererê,, Barreirinha e Curiri (Meso e Neo Devoniano) em Dois Poços na Porção Oeste da Bacia do Amazonas; MSc Dissertation, Universidade do Estado do Rio de Janeiro, Rio de Janeiro, Brazil, 2014, available at https://bdtd.ibict.br/vufind/Record/ UERJ_09ae4b64dd68b72e406519ab383090bb, accessed in July 2021.

15. Quijada, M.; Riboulleau, A.; Strother, P.; Taylor, W.; Mezzetti, A.; Versteegh, G. J. M.; Rev. Palaeobot. Palynol. 2016, 227, 52.

16. Espitalié, J.; Deroo, G.; Marquis, F.; Oil Gas Sci. Technol. 1986, 41,1986

17. Costa, J. A.; Mexias, A. S.; Gomes, M. E. B.; Ceramica 2010, 56,360 .

18. Duarte, A. F.; Gioda, A.; Lat. Am. J. Sedimentol. Basin Anal. 2014, 21, 3 .

19. Goes, J. R.; Azevedo, T. F.; Dutra, T. X. C.; Santos, V. B.; Severo Jr., J. B.; Barreto, L. S.; Ceramica 2014, 60, 211.

20. Guimarães, S. T.; Lima, H. N.; Teixeira, W. G.; Neves, A. F.; Silva, F. W. R.; Macedo, R. S.; de Souza, K. W.; Rev. Bras. Cienc. Solo 2013, 37, 317.

21. Varela, M. L.; do Nascimento, R. M.; Martinelli, A. E.; Hotza, D.; Melo, D. M. A.; Melo, M. A. F.; Ceramica 2005, 51, 387.

22. Peters, K. E.; Walters, C. C.; Moldowan, J. M.; The Biomarker Guide: Biomarkers and Isotopes in Petroleum Exploration and Earth History, vol. 2; Cambridge University Press: Cambridge, 2005.

23. Fabianska, M. J.; Szymczyk, A.; Chłapik, M.; Chem. Erde 2013, 74, 237.

24. Scalan, R. S.; Sxith, J. E.; Geochim. Cosmochim. Acta 1970, $34,611$.

25. Brassell, S. C.; Eglinton, G.; Howell, V. J.; Spec. Publ. - Geol. Soc. London 1987, 26, 79.

26. Tissot, B. P.; Welte, D. H.; Petroleum Formation and Occurrence, $2^{\text {nd }}$ ed.; Springer-Verlag: New York, USA, 1984.

27. Killops, S. D.; Killops, V. J.; Introduction to Organic Geochemistry; Wiley: New Jersey, 2005.

28. Dević, G. J.; Popović, Z. V.; Int. J. Coal Geol. 2013, 105, 48.

29. Hakimi, M. H.; Abdullah, W. H.; Al-Sharabi, M. S.; Al-Samawy, H. F.; Al-Borihee, K. M.; Al-Qahtani, M. H.; Makeen, Y. M.; Arabian J. Geosci. 2015, 8, 10151. 
30. Otto, A.; Simoneit, B. R. T.; Geochim. Cosmochim. Acta 2001, 65, 3505.

31. Brooks, J. D.; Gould, K.; Smith, J. W.; Nature 1969, 222, 257.

32. Kotarba, M. J.; Clayton, J. L.; Int. J. Coal Geol. 2003, 55, 73.

33. Papanicolaou, C.; Dehmer, J.; Fowler, M.; Int. J. Coal Geol. 2000, 44, 267.

34. Yu, Q.; Wen, Z.; Tang, Y.; Chin. J. Geochem. 2011, 30, 93.

35. Powell, T. G.; McKirdy, D. M.; Nature (London), Phys. Sci. 1973, 243, 37.

36. Grice, K.; Schaeffert, P.; Schwark, L.; Maxwell, J. R.; Org. Geochem. 1996, 25, 131.

37. Azevedo, D. A.; André Zinu, C. J.; Aquino Neto, F. R.; Simoneit, B. R. T.; Org. Geochem. 2001, 32, 443.

38. Leif, R. N.; Simoneit, B. R. T.; Org. Geochem. 1995, 23, 889.

39. Fowler, M. G.; Abolins, P.; Douglass, A. G.; Adv. Org. Geochemistry 1986, I, 815.

40. Fowler, M. G.; Stasiuk, L. D.; Hearn, M.; Obermajer, M.; Org. Geochem. 2004, 35, 425.

41. Reed, J. D.; Illich, H. A.; Horsfield, B.; Org. Geochem. 1986, $10,347$.

42. Rullkötter, J.; Spiro, B.; Nissenbaum, A.; Geochim. Cosmochim. Acta 1985, 49, 1357.

43. Hoffmann, C. F.; Foster, C. B.; Powell, T. G.; Summons, R. E.; Geochim. Cosmochim. Acta 1987, 51, 2681.

44. Suzuki, K.-I.; Saito, K.; Kawaguchi, A.; Okuda, S.; Komagata, K.; J. Gen. Appl. Microbiol. 1981, 27, 261.

45. Kannenberg, E.; Blume, A.; Poralla, K.; FEBS Lett. 1984, 172, 331.

46. Hatem, B. A.; Abdullah, W. H.; Hakimi, M. H.; Mustapha, K. A.; Mar. Pet. Geol. 2016, 72, 83.

47. Lerch, B.; Karlsen, D. A.; Seland, R.; Backer-Owe, K.; Pet. Geosci. 2017, 23, 190.

48. Roushdy, M. I.; El Nady, M. M.; Mostafa, Y. M.; El Gendy, N. S.; Ali, H. R.; J. Am. Sci. 2010, 6, 911.

49. Holba, A. G.; Dzou, L. I.; Wood, G. D.; Ellis, L.; Adam, P.; Schaeffer, P.; Albrecht, P.; Greene, T.; Hughes, W. B.; Org. Geochem. 2003, 34, 441.

50. Casilli, A.; Silva, R. C.; Laakia, J.; Oliveira, C. J. F.; Ferreira, A. A.; Regina, M.; Loureiro, B.; Azevedo, D. A.; Aquino, F. R.; Org. Geochem. 2014, 68, 61.

51. Mello, M. R.; Gaglianone, P. C.; Maxwell, J. R.; Mar. Pet. Geol. 1988, 5, 205.

52. Oliveira, C. R.; Ferreira, A. A.; Oliveira, C. J. F.; Azevedo, D. A.; Santos, E. V.; Aquino, F. R.; Org. Geochem. 2012, 46, 154.

53. Elias, V. O.; de Barros, A. M. A.; de Barros, A. B.; Simoneit, B. R. T.; Cardoso, J. N.; Org. Geochem. 1997, 26, 721.

54. Sonibare, O. O.; Ekweozor, C. M.; J. Appl. Sci. 2004, 4, 508.

55. Aquino Neto, F. R.; Trigois, I. J.; Azevedo, D. A.; Rodrigues, R.; Simoneit, B. R. T.; Org. Geochem. 1992, 18, 791.

56. Bin, C.; Tieguan, W.; Xiangchun, C.; Chin. J. Geochem. 2013, $32,347$.
57. Zumberge, J. E.; Org. Geochem. 1987, 51, 1625.

58. Huang, H.; Pearson, M.; Org. Geochem. 1999, 30, 1455.

59. Matsuda, N. S.; Winter, W. R.; Ribeiro, J.; Filho, W.; Bol. Geocienc. Petrobrás 2010, 18, 123.

60. Didyk, B. M.; Simoneit, B. R. T.; Brassell, S. C.; Eglinton, G.; Nature 1978, 272, 216.

61. Hunt, J. M.; Freeman, W. H.; Al., E.; Petroleum Geochemistry and Geology, $2^{\text {nd }}$ ed.; Freeman and Company: New York, 1996.

62. Sousa Jr., G. R.; Nogueira, A. C. R.; Santos Neto, E. V.; Moura, C. A. V.; Araújo, B. Q.; Reis, F. A. M.; J. South Am. Earth Sci. 2016, 72,7

63. Duan, Y.; Wang, C. Y.; Zheng, C. Y.; Wu, B. X.; Zheng, G. D.; J. Asian Earth Sci. 2008, 31, 341.

64. van Kaam-Peters, H. M. E.; Koster, J.; Van Der Gaast, S. J.; Dekker, M.; de Leeuw, J. W.; Damst', J. S. S.; Geochim. Cosmochim. Acta 1998, 62, 2923.

65. Romero, A. A. M.; Nguyen, T.; Am. Assoc. Pet. Geol. Bull. 2018, 102, 1379.

66. Rubinstein, I.; Strausz, O. P.; Geochim. Cosmochim. Acta 1979, $43,1387$.

67. Li, Q.; Ju, Y.; Chen, P.; Sun, Y.; Wang, M.; Li, X.; Chen, J.; Energy Fuels 2017, 31, 3567.

68. Rubinstein, B. I.; Sieskind, O.; Albrecht, P.; de Chimie, L.; S, N. A. C. N. R.; Chimie, D.; Pasteur, U. L.; Pascal, B.; J. Org. Chem 1975, 11, 1973.

69. Hughes, W. B. In Petroleum Geochemistry and Source Rock Potential of Carbonate Rocks, vol. 18; Palacas, J. G. ed.; American Association of Petroleum Geologists, 1984, p. 181.

70. Connan, J.; Bouroullec, J.; Dessort, D.; Albrecht, P.; Adv. Org. Geochem. 1986, 10, 29.

71. Gurgey, K.; J. Pet. Geol. 1999, 22, 167.

72. Abohajar, A.; Littke, R.; Schwarzbauer, J.; Weniger, P.; Boote, D. R. D.; J. Pet. Geol. 2015, 38, 119.

73. Holba, A. G.; Tegelaar, E.; Ellis, L.; Singletary, M. S.; Albrecht, P.; Geology 2000, 28, 251.

74. Volkman, J. K.; Geol. Soc. London, Spec. Publ. 1988, 103.

75. Volkman, J. K.; Appl. Microbiol. Biotechnol. 2003, 60, 495.

76. Hong, Y. J.; Giner, J. L.; Tantillo, D. J.; J. Org. Chem. 2013, 78, 935.

77. Giner, J.-L.; Djerassi, C.; J. Am. Chem. Soc. 1991, 113, 1386.

78. Bozcu, A.; Turk. J. Earth Sci. 2017, 26, 354.

79. El Nady, M. M.; El-naggar, A. Y.; Arabian J. Geosci. 2016, 9 , 627.

80. Farrimond, P.; Taylor, A.; TelnÆs, N.; Org. Geochem. 1998, 29, 1181.

81. Nytoft, H. P.; Bojesen-Koefoed, J. A.; Org. Geochem. 2001, 32, 841.

Submitted: May 12, 2021

Published online: November 18, 2021 